\title{
A Multi-Objective Stochastic Model for an Earthquake Relief Network
}

\author{
Zeren D. Yenice and Funda Samanlioglu \\ Department of Industrial Engineering, Kadir Has University, Kadir Has Campus, Cibali, Istanbul 34083, Turkey \\ Correspondence should be addressed to Funda Samanlioglu; fsamanlioglu@khas.edu.tr
}

Received 26 December 2018; Revised 27 June 2019; Accepted 6 September 2019; Published 15 January 2020

Academic Editor: Eneko Osaba

Copyright (C) 2020 Zeren D. Yenice and Funda Samanlioglu. This is an open access article distributed under the Creative Commons Attribution License, which permits unrestricted use, distribution, and reproduction in any medium, provided the original work is properly cited.

\begin{abstract}
Earthquake relief network involves storage and distribution of relief aid to people in need. In this paper, a new stochastic multiobjective mixed integer mathematical model is developed and implemented in Kadikoy municipality of Istanbul, Turkey in order to configure part of the earthquake relief network. The aim of the model is to help decision makers decide on the locations of storage areas for shelters pre-earthquake and distribution of shelters from these areas to temporary shelter areas post-earthquake while minimizing earthquake scenario-specific total expected distribution distance, total expected earthquake damage risk factor of storage areas and expected total penalty cost related to unsatisfied demand at temporary shelter areas, simultaneously. In the model, storage area capacity and coverage distance restrictions are taken into consideration. The data related to potential storage areas and shelter locations were obtained from Kadikoy municipality of Istanbul and Istanbul Metropolitan Municipality (IMM). The earthquake damage risk factors were determined based on possible earthquake scenarios given in Japan International Cooperation Agency's (JICA) report. Four event scenarios with two different earthquake scenario likelihoods were considered and sample efficient solutions from the Pareto frontier were obtained implementing the normalized (scaled) weighted sum method.
\end{abstract}

\section{Introduction}

Today's one of the prominent problems is natural disasters such as earthquakes. An accurate prediction of earthquakes is not yet possible, however it is possible to plan the stages of disaster operations management (mitigation, preparedness, response and recovery) based on several earthquake scenarios. Inefficient disaster management; emergency response and disaster relief may lead to starvation, diseases and eventually loss of lives even after an earthquake. Immediate typical needs post-earthquake are search and rescue operations, medical assistance, food and water procurement, and provision of temporary shelters. In this paper, a multi-objective stochastic model is developed to help decision makers in decisions related to storage and distribution of shelters.

Earthquake occurrence is the leading hazard in Turkey since the northern Anatolian fault crosses the country east to west, and the Anatolian fault north to south. $96 \%$ of the country's area is prone to earthquake risk and $66 \%$ contains active faults. Turkey went through several earthquake disasters in the century and based on the Japan International Cooperation Agency's (JICA) report [1], an earthquake is expected to occur in the following years at Marmara Sea which is very close to Istanbul and therefore people need to be prepared for it. An earthquake happened in August 17, 1999 and damaged several cities in the Marmara Region and the center of the earthquake was Golcuk. Estimated number of casualties were 15918, the number of heavily damaged houses were 66403, and the number of heavily damaged business units were 15000 [2]. Around $60 \%$ of these houses and business units collapsed immediately during the earthquake. Number of weakly or medium damaged houses were 146493 and number of weakly or medium damaged business units were 21000 [3]. As a result, around 120000 families needed immediate shelter after the earthquake in Golcuk which shows the significance of shelter storage and distribution problem.

In the literature, stochastic models are developed to handle mostly location, allocation, and distribution decisions related to logistics. Logendran and Terrell [4] developed a facility location model with stochastic demands and determined 
allocation of clients to uncapacitated plants. Louveaux and Peeters [5] presented a stochastic facility location model taking into consideration uncertain demands, uncertain transportation and production costs and uncertain selling prices with different event scenarios. Laporte et al. [6] studied location of facilities and allocation of customers to facilities as first-stage, and determination of quantities to send as second-stage decisions. Mousavi and Niaki [7] presented a capacitated location allocation problem where demands and locations of customers were uncertain. They assumed that demands are fuzzy and locations have normal probability distribution, and minimized fuzzy expected cost while finding optimal stochastic location.

Stochastic models are also used to handle uncertainties in health services, security systems, and service systems. Carson and Batta [8] constructed a location allocation model for preparing dynamic ambulance position plan for campus emergency service. Demands changed based on the scenarios and ambulances were relocated in each scenario based on minimization of average response time. Mestre et al. [9] developed a stochastic location allocation model for hospital network planning of Portuguese National Health Service, minimizing total expected travel time and total expected cost under demand uncertainty. Michalopoulos et al. [10] developed a stochastic network model to determine the (priority) list of locations of radiation detectors to build in order to prevent nuclear smuggling. They created possible threat scenarios by determining smuggler population. Khoo and Teoh [11] presented a methodology to determine optimal fleet management decisions taking into consideration stochastic travelers' demand.

A number of stochastic models in the disaster relief literature addressed the issues related to storage locations, inventory levels and distributions of relief supplies. Inventory and location decisions are long term strategic resource allocation decisions, typically done for preparedness pre-disaster and distribution decisions are short term allocation decisions, typically done for response post-disaster. However, several models integrate both preparedness and response decisions implementing scenario-based stochastic programming approaches. Pre-disaster operations are listed as evacuation from the potential disaster sites, stock pre-positioning and facility location and post disaster operations are given as evacuation to shelters, relief distribution and casualty transportation. In their literature survey, Altay and Green [12] identified research contributions in different stages of disaster operations management and listed these stages as mitigation, preparedness, response and recovery. Caunhye et al. [13] stated that emergency transportation operations were divided into three parts in the literature: facility locations, relief distribution and casualty transportation. For these three parts, they compared models based on their objective functions and constraints, and showed that location models that plan pre-disaster operations are single-period, whereas models that plan relief transportation post-disaster are mostly multi-period. Extensive literature reviews related to relief distribution networks, two-stage stochastic programs in disaster management with challenges and future research directions and facility locations in humanitarian relief can be found in Anaya-Arenas et al. [14], Grass and Fischer's [15] and Trivedi and Singh's [16] research, respectively.

Some of the stochastic models in the disaster relief literature include single objectives such as minimization of total cost, total delay, expected response time and maximization of total expected demand. Barbarosoglu and Arda [17] developed a two-stage stochastic multi-commodity, multi-modal network flow model to plan the transportation of vital first-aid commodities to disaster-affected areas, and validated the model with the data of 1997 Istanbul earthquake. In the model, resource requirements were taken as random variables and due to uncertainty of transportation systems in emergency situations, random arc capacities and supply amounts were used. The objective function was the minimization of the total first-stage transportation cost and the expected recourse cost which includes the total flow costs, mode shift costs and the penalty costs of inventory holding and shortage in the second stage. Chia [18] stated that the primary role of the logistic management in disasters is to deliver supplies in good conditions with the required quantities at the right time to the right place, while taking into consideration bottlenecks related to destruction of roads and security. Yi and Özdamar [19] introduced a location and distribution model that coordinates logistics and evacuation operations in emergency response management. The model was a mixed integer multi-commodity network flow model and its objective function was minimizing total delay in delivery of the commodities at aid centers and in the provision of healthcare for the injured survivors. Balcik and Beamon [20] introduced a maximal covering location model to maximize the total expected demand covered by distribution centers, while taking into consideration multiple item types, and budget and capacity restrictions. Rawls and Turnquist [21] presented a two-stage stochastic optimization model to pre-position various kinds of emergency supplies in storage areas pre-hurricane and to ship those to demand points post-hurricane and presented a case study focusing on the hurricane threat in the Gulf coast of US. In their model, they considered scenario-based demand locations, quantities, and transportation capacities, and minimized the total cost which includes fixed cost of opening storage facilities, acquisition cost for items, expected cost of shipment to demand points, expected holding cost of unused items and expected penalty cost for shortage at demand points. Duran et al. [22] developed a stochastic model to increase effectiveness of CARE's (Cooperative for Assistance and Relief Everywhere) average relief-aid emergency response time. The model included stochastic demands that change according to the disaster type and the objective was to minimize the expected response time. Davis et al. [23] developed a stochastic two stage expected cost minimization model in order to manage relief distribution before and after a hurricane. The first stage included preposition of relief goods between storage areas according to forecasts, and the second stage was the response phase that includes distribution of relief goods between storage points and demand points. Paul and MacDonald [24] developed a stochastic model to determine the location and capacity of distribution centers in order to mitigate the impacts of disasters with (almost) no forewarning such as earthquakes. The objective function in the model was 
to minimize the sum of expected fatality costs, supply costs and the costs of building distribution centers. Cavdur et al. [25] studied the allocation problem of temporary disaster response facilities and presented an earthquake case-study in Turkey. They developed a two-stage stochastic program, minimizing the total distance traveled, the unmet demand and the total number of facilities. Celik et al. [26] presented a two-stage mixed integer programming model that includes preposition of facility locations and pre-stocking levels of relief supplies along with minimization of total fixed facility locating cost at the first stage. At the second stage, proposed model allocates located distribution centers to affected locations and distributes relief supplies to demand points. They considered uncertainty in demand and minimized the expected cost of satisfying demand based on different scenarios. Maharjan and Hanaoka [27] determined the optimal number and location of warehouses for relief distribution problem in Nepal by modeling it as a modified maximal covering location problem. Mohamadi and Yaghoubi [28] presented a bi-objective stochastic optimization model for the location of transfer points and medical supplies distribution centers, taking into consideration triage system and failure of distribution centers and routes, and utilizing backup distribution centers. They converted the bi-objective model to a single-objective model with e-constraint method and presented a case study about the erathquake disaster in Iran.

Some stochastic models in the disaster relief literature include multiple objectives. Sheu [29] presented a dynamic multi-criteria relief demand management model to meet urgent relief demands based on time-varying relief demand and demand urgency of the affected area. Mete and Zabinsky [30] developed a two-stage stochastic programming model for storage and distribution of medical supplies and presented a case study in Seattle area. At the first stage, warehouse locations and inventory levels are determined minimizing the total warehouse operation cost and at the second stage, the amount of medical supplies to be distributed to the hospitals are determined minimizing the total transportation duration and the penalty of unfulfilled demand. Zhang et al. [31] introduced a node-weighted bottleneck Steiner tree based multi-objective location optimization model for emergency response logistics. The weights represented the importance of demand points and the model had two objective functions, minimizing the total distance and minimizing the maximum distance between facilities and demand points. Bozorgi-Amiri et al. [32] developed a bi-objective stochastic model for disaster relief logistics where the demands, supplies and the procurement and transportation costs were considered uncertain. The objectives in the model were minimization of the sum of the expected value and the variance of the total cost and penalty due to infeasibilities and minimization of the sum of the maximum shortages in the affected demand points. Najafi et al. [33] presented a multi-commodity, multi-mode and multi-period stochastic model to manage the logistics of commodities and injured people in the earthquake response. In their model, they minimized the total (weighted) unserved injured people, the total (weighted) unsatisfied demand, and the total number of used vehicles. Liberatore et al. [34] worked on distribution of emergency goods and presented a multi-criteria model called
RecHADS with a case study about 2010 Haiti earthquake. Their model included reliability and security attributes as well as cost attribute. Hong et al. [35] developed a goal programming multi-objective facility location model and presented a case study with the data of South Carolina, USA. In the model, the goals were about the minimization of total logistics costs that consist of fixed facility costs and transportation costs and the minimization of the expected number of disrupted relief items in an emergency logistics network. Tofighi et al. [36] presented a two-stage stochastic model for storage and distribution of critical and noncritical relief supplies and presented a case study in Tehran. At the first stage, they determined locations of warehouses and distribution centers along with inventory levels and capacities of warehouses, minimizing the total cost of operation warehouses and distribution centers and inventory costs. At the second stage, they planned the distribution of items, minimizing the total distribution time, the maximum weighted distribution time for the critical items and the total cost of unused inventories and the weighted shortage cost of unmet demands based on different scenarios. Moreno et al. [37] developed a two-stage stochastic location and transportation model which involves social concerns by considering deprivation costs in an emergency distribution network. At the first stage, they tried to obtain locations of relief centers and transportation capacities, minimizing costs of opening and operating relief centers and acquiring transportation capacities. At the second stage, they determined transportation of relief goods, minimizing total costs of acquiring extra transportation capacity, transportation costs, inventory holding costs and monetary cost of depriving victims.

In this paper, a multi objective stochastic mixed integer location and distribution model was developed in order to prepare an inventory and distribution plan and solve predicted shelter provision problem. In the model, the criteria considered were simultaneous minimization of total expected distribution distance, total expected earthquake damage risk factor of storage areas and total expected unsatisfied demand penalty cost of demand points. Here, total expected distribution distance was used as one of the objectives instead of total expected distribution cost or response time since in this research these are assumed to be positively correlated with the distribution distance. Here, locations of shelter storage areas (SA) are determined from potential SA and shelters are distributed from the SA to temporary shelter areas (TSA), taking into consideration earthquake scenario dependent demand, earthquake damage risk factor of storage areas, coverage distance and storage capacity restrictions. To the best of authors' knowledge, none of the stochastic models presented in the disaster relief literature include simultaneously these objectives and coverage distance and capacity restrictions. Kadikoy municipality in Istanbul Turkey was chosen as the pilot application area, and efficient solutions from the Pareto frontier were obtained in order to make decisions related to pre-earthquake shelter storage and post-earthquake shelter distribution to survivors. In Section 2, details of the mathematical model are presented, along with the normalized (scaled) weighted sum method implementation. Details of the application of the mathematical model in Turkey is given in Section 3, along 
with conclusions and suggestions for future directions in Section 4 .

\section{The Mathematical Model}

The proposed mathematical model is a stochastic multi-criteria mixed integer model. Expected values are optimized in stochastic models since uncertainty creates possible different probabilistic scenarios. The notation, parameters, and decision variables of the model are presented below.

Sets;

$S=\{n \mid n=1 \ldots N\} \quad$ set of SA.

$F \subset S \quad$ set of fixed SA.

$D=\{j \mid j=1 \ldots M\}$ set of TSA.

$S c=\{t \mid t=1 \ldots W\} \quad$ set of earthquake scenario in the model.

Decision Variables;

$A_{n}: \begin{cases}1 & \text { if storage area } n \text { is used for storing shelters } n \in S \\ 0 & \text { otherwise }\end{cases}$

$X_{n j t}$ : Amount of shelters sent from SA $n$ to TSA $j$ according to scenario $t, j \in D, t \in S c$.

$U_{j}$ : Amount of unsatisfied demand at TSA $j$ according to scenario $t, j \in D, t \in S c$.

$B_{n j t} \begin{cases}1 & \text { if storage area } n \text { servesto shelter } \\ \text { area } j \text { according to scenario } t, n \in S, j \in D, t \in S c & \text { otherwise }\end{cases}$

\section{Parameters;}

$P_{t}: \quad$ Probability of earthquake scenario $t, t \in S c$.

$C_{n}$ : Potential storage capacity of SA $n, n \in S$.

$R_{n t}$ : Potential earthquake damage risk factor of SA $n$ according to scenario $t, n \in S, t \in S c$.

$D_{j t}$ : Demand of TSA $j$ according to scenario $t, j \in D$ ,$t \in S c$.

$T_{n j}: \quad$ Distance between SA $n$ and TSA $j, n \in S, j \in D$.

$R_{j t}$ : Potential earthquake damage risk factor of TSA $j$ according to scenario $t, j \in D, t \in S c$.

$M_{j t}$ : Penalty cost for unsatisfied demand of TSA $j$ according to scenario $t, j \in D, t \in S c$.

$M_{j t}=L^{*} R_{j t} \forall j \in D, t \in S c$, where $L=\max _{n S}\left\{C_{n}\right\}$.

Useful Definitions;

Definition 1: $K$ is the distance limit for shelter allocation and defined as $K \approx\left[\max _{n \in S, j \in D}\left\{T_{n j}\right\}\right] / 2, K$ value can be changed according to decision maker's preference.

Definition 2: $H$ is a large enough number and defined as $H \approx \max _{n \in S}\left\{C_{n}\right\}$.

The mathematical model is as follows:

$$
\begin{gathered}
\text { Minimize } f_{1}(x)=\sum_{t \in S c} P_{t}\left\{\sum_{n \in S} \sum_{j \in D} T_{n j} B_{n j t}\right\} \\
\text { Minimize } f_{2}(x)=\sum_{t \in S c} P_{t}\left\{\sum_{n \in S} R_{n t} A_{n}\right\} .
\end{gathered}
$$

$$
\text { Minimize } f_{3}(x)=\sum_{t \in S c} P_{t}\left\{\sum_{j \in D} M_{j t} U_{j t}\right\} \text {. }
$$

s.t.

$$
\begin{gathered}
\sum_{j \in D} X_{n j t} \leq C_{n} A_{n} \forall n \in S, t \in S c . \\
\sum_{n \in S} X_{n j t}+U_{j t}=D_{j t} \forall j \in D, t \in S c . \\
X_{n j t} \leq H B_{n j t} \forall n \in S, j \in D, t \in S c . \\
A_{n}=1 \forall n \in F . \\
T_{n j} B_{n j t} \leq K \forall n \in S, j \in D, t \in S c . \\
B_{n j t} \leq A_{n} \forall n \in S, j \in D, t \in S c . \\
A_{n} \in\{0,1\} \forall n \in S . \\
B_{n j t} \in\{0,1\} \forall n \in S, j \in D, t \in S c . \\
X_{n j t} \geq 0 \forall n \in S, j \in D, t \in S c . \\
U_{j t} \geq 0 \forall j \in D, t \in S c .
\end{gathered}
$$

The first objective function (1) is the minimization of total expected distribution distance between SA and TSA. Second objective function (2) is the minimization of total expected earthquake damage risk factor of SA. Third objective function (3) is the minimization of total expected penalty cost related to unsatisfied demand at TSA. Note that, in (3) penalty cost of unsatisfied demand at TSA depends on the potential earthquake damage risk factor of TSA. Constraint (4) limits the distribution of shelters from SA to SA's storage capacity. Constraint (5) is about the satisfaction of demand at TSA. Constraint (6) is to relate $X_{n j t}$ and $B_{n j t}$ variables and assign " 1 " to variable $B_{n j t}$ if related SA sends shelter(s) to TSA. Constraint (7) is to mark fixed SA (already decided storage areas). Constraint (8) is the coverage distance restriction for distribution of shelters from SA to TSA. Constraint (9) is to relate $B_{n j t}$ and $A_{n}$ variables and to ensure that only used SA serves to TSA. Constraints (10) and (11) are for binary decision variables and Constraints (12) and (13) are nonnegativity restrictions.

In this paper, a three-objective mathematical model is formulated in order to simultaneously consider three objectives and due to its simplicity, normalized (scaled) weighted sum method is used to obtain representative efficient solutions from the Pareto frontier. The solution of (normalized) weighted sum problem is efficient (Pareto optimal) if all weights are positive [38].

A MOP, $\min f(x)=\left\{f_{1}(x), f_{2}(x), \ldots, f_{k}(x),\right\}$ s.t. $x \in X$ is assumed to have $k$ competing objective functions $\left(f_{i}: \mathbb{R}^{n} \rightarrow \mathbb{R}\right)$ that are to be minimized simultaneously.

Definition 1. A decision vector $x^{\prime} \in X$ is efficient (Pareto optimal) for MOP if there does not exist a $x \in X, x \neq x^{\prime}$ such 
that $f_{i}(x) \leq f_{i}\left(x^{\prime}\right)$ for $i=1, \ldots, k$ with strict inequality holding for at least one index $i$. ( $x^{\prime} \in X$ is efficient, $f_{i}\left(x^{\prime}\right)$ is non-dominated.)

Definition 2. A decision vector $x^{\prime} \in X$ is weakly efficient (weakly Pareto optimal) for MOP if there does not exist a $x \in X, x \neq x^{\prime}$ such that $f_{i}(x)<f_{i}\left(x^{\prime}\right)$ for $i=1, \ldots, k .\left(x^{\prime} \in X\right.$ is weakly efficient, $f_{i}\left(x^{\prime}\right)$ is weakly non-dominated.)

The normalized weighted sum formulation of this problem is given in (14) as:

$$
\min z=\sum_{i=1}^{i=3} w_{i}\left[\frac{f_{i}(x)-f_{i}^{*}(x)}{\left|f_{i}^{*}(x)-f_{i}^{n}(x)\right|}\right],
$$

s.t. (4)-(13).

where $w_{i}>0$ are the importance weights $\left(\sum_{i=1}^{i=3} w_{i}=1\right)$, $f_{i}^{*}(x) \quad(i=1,2,3)$ is the utopia point defined as $f_{i}^{*}(x)=\min _{x \in X} f_{i}(x)-\delta_{i}=$ for $i=1,2,3\left(\delta_{i}>0\right)$ and $f_{i}^{n}(x)$ $(i=1,2,3)$ is the nadir point defined as the upper bound of the Pareto optimal set. Problem (14) with different weights $\left(w_{i}<0\right.$ and $\left.\sum_{i} w_{i}=1\right)$ is solved each time to obtain several representative efficient solutions of the problem.

\section{Application in Turkey}

The mathematical model is applied in Kadikoy municipality of Istanbul, Turkey. The data related to the potential SA and TSA were obtained from Kadikoy municipality of Istanbul and Istanbul Metropolitan Municipality (IMM). Kadikoy municipality has 21 neighborhoods and in the paper for simplicity these neighborhoods are given numbers as: Caferaga (1), Osmanaga (2), Rasimpasa (3), Kosuyolu (4), Acibadem (5), Hasanpasa (6), Zuhtupasa (7), Egitim (8), Fikirtepe (9), Dumlupinar (10), Feneryolu (11), Merdivenkoy (12), Goztepe (13), Fenerbahce (14), Caddebostan (15), Erenkoy (16), Suadiye (17), Bostanci (18), Kozyatagi (19), 19 Mayis (20) and Sahrayicedit (21). The earthquake damage risks were determined based on possible earthquake scenarios presented in JICA report [1]. JICA team created four possible earthquake scenarios for fault line breakdowns of the expected earthquake in Turkey. These four earthquake scenarios were created based on historical earthquakes and North Anatolian fault line and listed below.

Model A: Approximately $120 \mathrm{~km}$ long fault line of 1999 Izmit earthquake causes disaster and seismic activity goes from east to west. Moment magnitude was assumed to be $7.5 \mathrm{Mw}$.

Model B: Approximately $110 \mathrm{~km}$ long fault line of 1912 Murefte-Sarkoy earthquake causes disaster and its moment magnitude was expected to be 7.4 Mw.

Model C: This scenario assumes that $170 \mathrm{~km}$ long North Anatolian fault line in Marmara Sea will break at the same time. The moment magnitude is expected to be $7.7 \mathrm{Mw}$. It is the biggest magnitude that will occur in this area. The largest earthquake that has occurred around the Marmara Sea in the history has $7.6 \mathrm{Mw}$ moment magnitude.
TABLE 1: Event scenarios.

\begin{tabular}{lcc}
\hline $\begin{array}{l}\text { Event } \\
\text { scenario no }\end{array}$ & $\begin{array}{c}\text { Probability of model A } \\
\text { (earthquake scenario 1) }\end{array}$ & $\begin{array}{c}\text { Probability of model C } \\
\text { (earthquake scenario 2) }\end{array}$ \\
\hline 1 & 0.9 & 0.1 \\
2 & 0.8 & 0.2 \\
3 & 0.7 & 0.3 \\
4 & 0.6 & 0.4 \\
\hline
\end{tabular}

Model D: This scenario assumes that the fault line in the north of Marmara Sea intersects with Cinarcik Graben and creates earthquake which has 6.7 Mw moment magnitude.

Among these 4 earthquake scenarios, Model A has the greatest probability to take place and Model $C$ is the worst-case scenario to happen. In the JICA report [1], detailed data were available only for these two earthquake scenarios, so in this application only Model A (earthquake scenario 1) and Model C (earthquake scenario 2) were considered. In Tables 1, 4 event scenarios were created taking into consideration that Model A (earthquake scenario 1) is more likely to occur than Model $\mathrm{C}$ (earthquake scenario 2) based on the JICA report [1].

JICA report [1] contains maps of Istanbul with color-coded areas that are based on the expected number of heavily damaged buildings and seismic intensity for both Model A and C. These maps are given in Figures 1-4. Red and orange colored areas will be affected heavily, yellow colored areas will suffer moderate level damage, green and blue colored areas will be affected lightly from the earthquake. From these maps, Kadiköy municipality is enlarged and related maps of Kadiköy municipality are given in Figures 5-8. In Figure 5, previously listed neighborhood numbers of Kadiköy municipality are also presented to show the readers the locations of these neighborhoods and potential SA and TSA. These maps are used to determine the potential earthquake damage risk factors of SA and TSA. For model A (earthquake scenario 1) and C (earthquake scenario 2), risk factor of each SA and TSA was calculated, depending on the neighborhood it is located at, as the average of damaged building factor, seismic damage factor and closeness to sea side factor due to possibility of tsunami. The neighborhoods of Kadiköy and related risk factors are given in Table 2. Damaged building factor and seismic damage factor were determined from color-coded hazard maps of JICA report [1], which are given in Figures 1-8. For these factors, numerical values $1-5$ were assigned, 5 for very high risk and 1 for very low risk. Areas close to sea could be damaged more than far ones due to tsunami and south shores of Istanbul might be damaged as a result of an earthquake affecting Marmara Sea. To determine closeness to sea side factor of each SA and TSA, numerical values $1-5$ were assigned, 5 for very close and 1 for very far.

In Table 3, 12 TSA and related shelter demands and earthquake damage risk factors are given for both earthquake scenario 1 (Model A) and 2 (Model C). Amount of required shelters (demands) were calculated by IMM Disaster Coordination Center (AKOM) according to the sizes of TSA and those quantities were used as demands for the worst-case earthquake scenario (model C, earthquake scenario 2). Based on the JICA report [1], Model C has 2313 units of heavily 
TABLE 2: Risk factors of neighborhoods of Kadiköy municipality for model A (earthquake scenario 1) and C (earthquake scenario 2).

\begin{tabular}{|c|c|c|c|c|c|c|c|c|}
\hline \multirow[b]{2}{*}{ Neighborhood } & \multicolumn{4}{|c|}{ Model A (earthquake scenario 1) } & \multicolumn{4}{|c|}{ Model C (earthquake scenario 2) } \\
\hline & $\begin{array}{c}\text { Damaged } \\
\text { building } \\
\text { factor }\end{array}$ & $\begin{array}{c}\text { Seismic } \\
\text { damage } \\
\text { factor }\end{array}$ & $\begin{array}{c}\text { Closeness } \\
\text { to sea side } \\
\text { factor }\end{array}$ & Risk factor & $\begin{array}{c}\text { Damaged } \\
\text { building } \\
\text { factor }\end{array}$ & $\begin{array}{c}\text { Seismic } \\
\text { damage } \\
\text { factor }\end{array}$ & $\begin{array}{c}\text { Closeness } \\
\text { to sea side } \\
\text { factor }\end{array}$ & Risk factor \\
\hline Caferaga (1) & 4 & 2 & 4 & 3.33 & 4 & 3 & 4 & 3.67 \\
\hline Osmanaga (2) & 3 & 2 & 3 & 2.67 & 4 & 3 & 3 & 3.33 \\
\hline Rasimpasa (3) & 4 & 2 & 4 & 3.33 & 4 & 3 & 4 & 3.67 \\
\hline Kosuyolu (4) & 3 & 2 & 2 & 2.33 & 4 & 2 & 2 & 2.67 \\
\hline Acibadem (5) & 2 & 2 & 2 & 2.00 & 3 & 2 & 2 & 2.33 \\
\hline Hasanpasa (6) & 4 & 3 & 3 & 3.33 & 4 & 3 & 3 & 3.33 \\
\hline Zuhtupasa (7) & 3 & 3 & 4 & 3.33 & 3 & 3 & 4 & 3.33 \\
\hline Egitim (8) & 3 & 3 & 2 & 2.67 & 4 & 3 & 2 & 3.00 \\
\hline Fikirtepe (9) & 4 & 3 & 1 & 2.67 & 4 & 3 & 1 & 2.67 \\
\hline Dumlupinar (10) & 3 & 2 & 1 & 2.00 & 3 & 2 & 1 & 2.00 \\
\hline Feneryolu (11) & 2 & 2 & 3 & 2.33 & 2 & 3 & 3 & 2.67 \\
\hline Merdivenkoy (12) & 3 & 2 & 1 & 2.00 & 3 & 3 & 1 & 2.33 \\
\hline Goztepe (13) & 2 & 2 & 3 & 2.33 & 3 & 2 & 3 & 2.67 \\
\hline Fenerbahce (14) & 2 & 3 & 4 & 3.00 & 3 & 3 & 4 & 3.33 \\
\hline Caddebostan (15) & 2 & 2 & 4 & 2.67 & 2 & 3 & 4 & 3.00 \\
\hline Erenkoy (16) & 2 & 2 & 3 & 2.33 & 3 & 2 & 3 & 2.67 \\
\hline Suadiye (17) & 2 & 3 & 4 & 3.00 & 3 & 3 & 4 & 3.33 \\
\hline Bostanci (18) & 2 & 2 & 4 & 2.67 & 3 & 3 & 4 & 3.33 \\
\hline Kozyatagi (19) & 2 & 2 & 3 & 2.33 & 2 & 2 & 3 & 2.33 \\
\hline 19 Mayis (20) & 2 & 2 & 2 & 2.00 & 2 & 2 & 2 & 2.00 \\
\hline Sahrayicedit (21) & 2 & 2 & 1 & 1.67 & 2 & 2 & 1 & 1.67 \\
\hline
\end{tabular}

TABLE 3: Data of temporary shelter areas (TSA).

\begin{tabular}{|c|c|c|c|c|c|c|}
\hline ID & $\begin{array}{l}\text { Place and (Neighbor- } \\
\text { hood) }\end{array}$ & Area $\left(\mathrm{m}^{2}\right)$ & $\begin{array}{l}\text { Shelter demands } \\
\text { (model A) }\end{array}$ & $\begin{array}{l}\text { Shelter demands } \\
\text { (model C) }\end{array}$ & $\begin{array}{l}\text { Risk factors }\left(\mathrm{R}_{\mathrm{j} 1}\right) \text { of } \\
\text { model } \mathrm{A}\end{array}$ & $\begin{array}{l}\text { Risk factors }\left(\mathrm{R}_{\mathrm{j} 2}\right) \text { of } \\
\text { model } \mathrm{C}\end{array}$ \\
\hline 100 & Kosuyolu park, (4) & 12000 & 192 & 240 & 2.33 & 2.67 \\
\hline 101 & $\begin{array}{l}\text { Kadikoy Municipali- } \\
\text { ty parking area, (6) }\end{array}$ & 17000 & 272 & 340 & 3.33 & 3.33 \\
\hline 102 & Yogurtcu park, (2) & 25000 & 400 & 500 & 2.67 & 3.33 \\
\hline 103 & $\begin{array}{l}\text { Kadikoy Anadolu } \\
\text { Lisesi, (1) }\end{array}$ & 22000 & 352 & 440 & 3.33 & 3.67 \\
\hline 104 & $\begin{array}{c}\text { Moda bazaar area } \\
\text { and parking area, (1) }\end{array}$ & 8000 & 128 & 160 & 3.33 & 3.67 \\
\hline 105 & $\begin{array}{l}\text { Fenerbahce park, } \\
\text { (14) }\end{array}$ & 60000 & 960 & 1200 & 3.00 & 3.33 \\
\hline 106 & IETT bus station, (8) & 8000 & 128 & 160 & 2.67 & 3 \\
\hline 107 & $\begin{array}{l}\text { Fenerbahce sport } \\
\text { facilities, (10) }\end{array}$ & 19000 & 304 & 380 & 2.00 & 2 \\
\hline 108 & $\begin{array}{l}\text { Selamicesme Ozgur- } \\
\text { luk park, (13) }\end{array}$ & 120000 & 1920 & 2400 & 2.33 & 2.67 \\
\hline 109 & Goztepe park, (15) & 90000 & 1440 & 1800 & 2.67 & 3 \\
\hline 110 & Cebe sokak, (21) & 70000 & 1120 & 1400 & 1.67 & 1.67 \\
\hline 111 & $\begin{array}{c}\text { Bostanci bazaar area, } \\
\text { (18) }\end{array}$ & 30000 & 480 & 600 & 2.67 & 3.33 \\
\hline
\end{tabular}

buildings and model A has 1944 units. There is about $17 \%$ difference between these scenarios in terms of heavily damaged buildings and seismic intensity will also be lower in model A. So, model A's (earthquake scenario 1) demands were assumed to be approximately 20\% lower than Model C's (earthquake scenario 2) demands.

88 potential SA were considered in this research, and these were available public schools in Kadikoy. Also, in Chen et al. 
TABLE 4: Earthquake damage risk factors (RF) of storage areas (SA) based on model A (RF-A) and model C (RF-C) and shelter capacities in units.

\begin{tabular}{|c|c|c|c|c|c|c|c|c|c|}
\hline ID & $\begin{array}{c}\text { SA and } \\
\text { (neigborhood) }\end{array}$ & RF-A & RF-C & Shelter capacity & ID & SA and (neighborhood) & RF-A & RF-C & $\begin{array}{l}\text { Shelter } \\
\text { capacity }\end{array}$ \\
\hline 1 & $\begin{array}{l}29 \text { Ekim Ilkokulu, } \\
\text { (13) }\end{array}$ & 2.33 & 2.67 & 250 & 45 & $\begin{array}{c}\text { Ilhami Ahmed Ornekal Orta- } \\
\text { okulu, (13) }\end{array}$ & 2.33 & 2.67 & 500 \\
\hline 2 & $\begin{array}{l}30 \text { Agustos Ilkokulu, } \\
(20)\end{array}$ & 2.00 & 2.00 & 250 & 46 & Ilhami Ertem Ortaokulu, (19) & 2.33 & 2.33 & 500 \\
\hline 3 & $\begin{array}{l}\text { 60.Yil Anadolu } \\
\text { Ilkokulu, (5) }\end{array}$ & 2.00 & 2.33 & 500 & 47 & $\begin{array}{l}\text { Kazim Karabekir } \\
\text { Ortaokulu, }(20)\end{array}$ & 2.00 & 2.00 & 250 \\
\hline 4 & $\begin{array}{l}\text { Bostanci Ilkokulu, } \\
\text { (18) }\end{array}$ & 2.67 & 3.33 & 250 & 48 & $\begin{array}{c}\text { Mehmet Sait Aydoslu Isitme } \\
\text { Engelliler } \\
\text { Ortaokulu, (13) }\end{array}$ & 2.33 & 2.67 & 500 \\
\hline 5 & $\begin{array}{l}\text { Cemal Diker } \\
\text { Ilkokulu, (19) }\end{array}$ & 2.33 & 2.33 & 250 & 49 & $\begin{array}{l}\text { Melahat Sefizade } \\
\text { Ortaokulu, (11) }\end{array}$ & 2.33 & 2.67 & 250 \\
\hline 6 & $\begin{array}{l}\text { Cenap Sehabettin } \\
\text { Ilkokulu, (4) }\end{array}$ & 2.33 & 2.67 & 500 & 50 & $\begin{array}{l}\text { Melehat Akkutlu } \\
\text { Ortaokulu, (12) }\end{array}$ & 2.00 & 2.33 & 500 \\
\hline 7 & $\begin{array}{l}\text { Dr. Sait Darga } \\
\text { Ilkokulu, (5) }\end{array}$ & 2.00 & 2.33 & 250 & 51 & $\begin{array}{l}\text { Mustafa Mihriban Boysan } \\
\text { Ortaokulu, (17) }\end{array}$ & 3.00 & 3.33 & 250 \\
\hline 8 & $\begin{array}{l}\text { Erenkoy Ilkokulu, } \\
\qquad(16)\end{array}$ & 2.33 & 2.67 & 500 & 52 & $\begin{array}{l}\text { Nevzad Ayasbeyoglu } \\
\text { Ortaokulu, (21) }\end{array}$ & 1.67 & 1.67 & 250 \\
\hline 9 & $\begin{array}{l}\text { Gazi Mustafa Kemal } \\
\text { Pasa Ilkokulu, (2) }\end{array}$ & 2.67 & 3.33 & 250 & 53 & $\begin{array}{l}\text { Nurettin Teksan } \\
\text { Ortaokulu, (14) }\end{array}$ & 3.00 & 3.33 & 500 \\
\hline 10 & $\begin{array}{l}\text { Goztepe Ilkokulu, } \\
\text { (13) }\end{array}$ & 2.33 & 2.67 & 250 & 54 & $\begin{array}{l}\text { Resat Nuri Guntekin } \\
\text { Ortaokulu, (4) }\end{array}$ & 2.33 & 2.67 & 500 \\
\hline 11 & $\begin{array}{l}\text { Halil Turkkan } \\
\text { Ilkokulu, (4) }\end{array}$ & 2.33 & 2.67 & 250 & 55 & Yesilbahar Ortaokulu, (13) & 2.33 & 2.67 & 500 \\
\hline 12 & $\begin{array}{l}\text { Ibrahim Oktem } \\
\text { Ilkokulu, (7) }\end{array}$ & 3.33 & 3.33 & 250 & 56 & Zuhtupasa Ortaokulu, (7) & 3.33 & 3.33 & 250 \\
\hline 13 & $\begin{array}{l}\text { Ihsan Sungu } \\
\text { Ilkokulu, (3) }\end{array}$ & 3.33 & 3.67 & 500 & 57 & $\begin{array}{l}\text { Istanbul Avni Akyol Guzel } \\
\text { Sanatlar Lisesi, (13) }\end{array}$ & 2.33 & 2.67 & 750 \\
\hline 14 & $\begin{array}{l}\text { Ilhami Ahmed } \\
\text { Ornekal Ilkokulu, } \\
\text { (14) }\end{array}$ & 3.00 & 3.33 & 500 & 58 & $\begin{array}{l}\text { Erenkoy Kiz Anadolu } \\
\text { Lisesi, (16) }\end{array}$ & 2.33 & 2.67 & 500 \\
\hline 15 & Inonu Ilkokulu, (8) & 2.67 & 3.00 & 750 & 59 & $\begin{array}{l}\text { Fenerbahce Anadolu } \\
\text { Lisesi, (13) }\end{array}$ & 2.33 & 2.67 & 750 \\
\hline 16 & $\begin{array}{c}\text { Kalamis Sehit Murat } \\
\text { Ozyalcin Ilkokulu, } \\
(14)\end{array}$ & 3.00 & 3.33 & 250 & 60 & $\begin{array}{l}\text { Goztepe Ihsan Kursunoglu } \\
\text { Anadolu Lisesi, (13) }\end{array}$ & 2.33 & 2.67 & 500 \\
\hline 17 & $\begin{array}{l}\text { Kaptan Hasanpasa } \\
\text { Ilkokulu, (6) }\end{array}$ & 3.33 & 3.33 & 250 & 61 & $\begin{array}{l}\text { Hayrullah Kefoglu } \\
\text { Anadolu Lisesi, (18) }\end{array}$ & 2.67 & 3.33 & 250 \\
\hline 18 & $\begin{array}{l}\text { Kozyatagi Sukran } \\
\text { Karabelli Ilkokulu, } \\
\text { (19) }\end{array}$ & 2.33 & 2.33 & 500 & 62 & Istanbul Anadolu Lisesi, (7) & 3.33 & 3.33 & 1000 \\
\hline 19 & $\begin{array}{l}\text { Leman Kaya Ilkokulu } \\
\text { (18) }\end{array}$ & 2.67 & 3.33 & 250 & 63 & $\begin{array}{l}\text { Istanbul Kadikoy } \\
\text { Lisesi, (1) }\end{array}$ & 3.33 & 3.67 & 250 \\
\hline 20 & $\begin{array}{l}\text { Mehmet Karamanci } \\
\text { Ilkokulu, (17) }\end{array}$ & 2.33 & 2.67 & 500 & 64 & $\begin{array}{l}\text { Kadikoy Anadolu } \\
\text { Lisesi, (1) }\end{array}$ & 3.33 & 3.67 & 1250 \\
\hline 21 & $\begin{array}{l}\text { Mehmet Sait Aydoslu } \\
\text { Isitme Engelliler } \\
\text { Ilkokulu, (13) }\end{array}$ & 2.33 & 2.67 & 500 & 65 & $\begin{array}{l}\text { Kazim Ismen Anadolu } \\
\text { Lisesi, (4) }\end{array}$ & 2.33 & 2.67 & 500 \\
\hline 22 & Moda Ilkokulu, (1) & 3.33 & 3.67 & 250 & 66 & $\begin{array}{l}\text { Kemal Ataturk Anadolu } \\
\text { Lisesi, (2) }\end{array}$ & 2.67 & 3.33 & 750 \\
\hline 23 & $\begin{array}{l}\text { Mustafa Aykin } \\
\text { Ilkokulu, (11) }\end{array}$ & 2.33 & 2.67 & 750 & 67 & $\begin{array}{l}\text { Mustafa Saffet Anadolu } \\
\text { Lisesi, (12) }\end{array}$ & 2.00 & 2.33 & 250 \\
\hline 24 & $\begin{array}{l}\text { Nihat Isik Ilkokulu, } \\
\text { (2) }\end{array}$ & 2.67 & 3.33 & 500 & 68 & $\begin{array}{c}\text { Suadiye Haci Mustafa } \\
\text { Tarman Anadolu Lisesi, (17) }\end{array}$ & 3.00 & 3.33 & 500 \\
\hline 25 & $\begin{array}{l}\text { Ogretmen Harun } \\
\text { Resit Ilkokulu, (13) }\end{array}$ & 2.33 & 2.67 & 250 & 69 & $\begin{array}{c}\text { Istanbul Ataturk Fen } \\
\text { Lisesi, (8) }\end{array}$ & 2.67 & 3.00 & 500 \\
\hline
\end{tabular}


TABLE 4: Continued.

\begin{tabular}{|c|c|c|c|c|c|c|c|c|c|}
\hline ID & $\begin{array}{c}\text { SA and } \\
\text { (neigborhood) }\end{array}$ & RF-A & RF-C & Shelter capacity & ID & SA and (neighborhood) & RF-A & RF-C & $\begin{array}{l}\text { Shelter } \\
\text { capacity }\end{array}$ \\
\hline 26 & $\begin{array}{l}\text { Osmangazi Ilkokulu, } \\
\text { (3) }\end{array}$ & 3.33 & 3.67 & 250 & 70 & $\begin{array}{c}\text { 50.Yil Cumhuriyet Feridun } \\
\text { Tumer Cok Programli Lisesi, } \\
\text { (14) }\end{array}$ & 3.00 & 3.33 & 250 \\
\hline 27 & $\begin{array}{l}\text { Sener Birsoz } \\
\text { Ilkokulu, (21) }\end{array}$ & 1.67 & 1.67 & 250 & 71 & $\begin{array}{l}\text { Ahmet Sani Gezici Lisesi Kiz } \\
\text { Teknik ve Meslek Lisesi, (5) }\end{array}$ & 2.00 & 2.33 & 250 \\
\hline 28 & $\begin{array}{c}\text { Turhan Mediha } \\
\text { Tansel Ilkokulu, (17) }\end{array}$ & 2.33 & 2.67 & 250 & 72 & $\begin{array}{l}\text { General Ali Riza Ersin Teknik } \\
\text { ve Endustri Meslek Lisesi, (5) }\end{array}$ & 2.00 & 2.33 & 250 \\
\hline 29 & $\begin{array}{c}\text { Zihnipasa } \\
\text { Ilkokulu, (16) }\end{array}$ & 2.33 & 2.67 & 250 & 73 & $\begin{array}{c}\text { Kadikoy Kiz Teknik ve Meslek } \\
\text { Lisesi, (1) }\end{array}$ & 3.33 & 3.67 & 250 \\
\hline 30 & $\begin{array}{l}\text { Zuhtupasa } \\
\text { Ilkokulu, (7) }\end{array}$ & 3.33 & 3.33 & 250 & 74 & $\begin{array}{l}\text { Kadikoy Muhsin Adil Binal } \\
\text { Ticaret Meslek Lisesi, (1) }\end{array}$ & 3.33 & 3.67 & 250 \\
\hline 31 & $\begin{array}{l}23 \text { Nisan Zehra } \\
\text { Hanim Imam Hatip } \\
\text { Ortaokulu, (18) }\end{array}$ & 2.67 & 3.33 & 500 & 75 & $\begin{array}{c}\text { Kadikoy Ticaret Meslek } \\
\text { Lisesi, (13) }\end{array}$ & 2.33 & 2.67 & 250 \\
\hline 32 & $\begin{array}{l}\text { Mehmet Akif Imam } \\
\text { Hatip Ortaokulu, } \\
\text { (20) }\end{array}$ & 2.00 & 2.00 & 250 & 76 & $\begin{array}{l}\text { Mehmet Beyazid Anadolu } \\
\text { Saglik Meslek Lisesi, (10) }\end{array}$ & 2.00 & 2.00 & 250 \\
\hline 33 & $\begin{array}{c}\text { Bahariye } \\
\text { Ortaokulu, (1) }\end{array}$ & 3.33 & 3.67 & 500 & 77 & $\begin{array}{l}\text { Hamit Ibrahimiye Otistik } \\
\text { Cocuklar Egt. Merkezi, (12) }\end{array}$ & 2.00 & 2.33 & 250 \\
\hline 34 & $\begin{array}{l}\text { Bostanci Ataturk } \\
\text { Ortaokulu, (18) }\end{array}$ & 2.67 & 3.33 & 500 & 78 & $\begin{array}{l}\text { Hayriye-Kemal Kusun Egt } \\
\text { Uyg.Ok.ve Is Egt. M, (1) }\end{array}$ & 3.33 & 3.67 & 250 \\
\hline 35 & $\begin{array}{c}\text { Erenkoy Mehmet Sait } \\
\text { Aydoslu } \\
\text { Ortaokulu, (16) }\end{array}$ & 2.33 & 2.67 & 250 & 79 & $\begin{array}{l}\text { Mediha-Turhan Tansel Egt } \\
\text { Uyg.Ok.ve Is Eg. M, (16) }\end{array}$ & 2.33 & 2.67 & 250 \\
\hline 36 & $\begin{array}{l}\text { Faik Resit Unat Orta- } \\
\text { okulu, (13) }\end{array}$ & 2.33 & 2.67 & 250 & 80 & $\begin{array}{l}\text { Sohret Kursunoglu Ilkogretim } \\
\text { Okulu ve Is Okulu, }(20)\end{array}$ & 2.00 & 2.00 & 250 \\
\hline 37 & $\begin{array}{l}\text { Fehmi Eksioglu } \\
\text { Ortaokulu, (16) }\end{array}$ & 2.33 & 2.67 & 500 & 81 & $\begin{array}{l}\text { Gozcubaba Imam Hatip } \\
\text { Lisesi, (12) }\end{array}$ & 2.00 & 2.33 & 250 \\
\hline 38 & $\begin{array}{l}\text { Gazi Mustafa Kemal } \\
\text { Pasa Ortaokulu, (2) }\end{array}$ & 2.67 & 3.33 & 750 & 82 & Intas Imam Hatip Lisesi, (16) & 2.33 & 2.67 & 250 \\
\hline 39 & $\begin{array}{l}\text { Goztepe H. Halil } \\
\text { Turkkan } \\
\text { Ortaokulu, (12) }\end{array}$ & 2.00 & 2.33 & 250 & 83 & $\begin{array}{l}\text { Kadikoy Erkek Anadolu } \\
\text { Imam Hatip lisesi, (6) }\end{array}$ & 3.33 & 3.33 & 250 \\
\hline 40 & $\begin{array}{c}\text { Goztepe } \\
\text { Ortaokulu, (13) }\end{array}$ & 2.33 & 2.67 & 250 & 84 & $\begin{array}{l}\text { Kadikoy Kiz Anadolu Imam } \\
\text { Hatip Lisesi, (5) }\end{array}$ & 2.00 & 2.33 & 250 \\
\hline 41 & $\begin{array}{l}\text { Hakki Deger Orta- } \\
\text { okulu, (19) }\end{array}$ & 2.33 & 2.33 & 250 & 85 & $\begin{array}{l}\text { Marmara University } \\
\text { Campus } 1,(5)\end{array}$ & 2.00 & 2.33 & 1000 \\
\hline 42 & $\begin{array}{l}\text { Halil Turkkan } \\
\text { Ortaokulu, (13) }\end{array}$ & 2.33 & 2.67 & 500 & 86 & $\begin{array}{l}\text { Marmara University } \\
\text { Campus 2, (13) }\end{array}$ & 2.33 & 2.67 & 2000 \\
\hline 43 & $\begin{array}{l}\text { Huseyin Ayaz } \\
\text { Ortaokulu, (10) }\end{array}$ & 2.00 & 2.00 & 500 & 87 & $\begin{array}{l}\text { Marmara University } \\
\text { Campus } 3,(6)\end{array}$ & 3.33 & 3.33 & 1250 \\
\hline 44 & $\begin{array}{c}\text { Ikbaliye Erdogan } \\
\text { Yuksel Ortaokulu, (6) }\end{array}$ & 3.33 & 3.33 & 250 & 88 & $\begin{array}{l}\text { Istanbul Medeniyet } \\
\text { Universitesi, (10) }\end{array}$ & 2.00 & 2.00 & 2000 \\
\hline
\end{tabular}

[39] research, potential shelter locations in a pilot area in China were analyzed and $41 \%$ of potential shelter locations were determined to be school playgrounds. For model A (earthquake scenario 1) and $\mathrm{C}$ (earthquake scenario 2), risk factor of each SA was calculated, depending on the neighborhood it is located at, using the risk factor of neighborhoods in Table 2. Shelter capacity of each SA was determined based on the size of its' garden, since shelters are planned to be stored in standard transportation containers at the gardens of schools for storage and transportation convenience. In Table 4, 88 SA are presented along with their shelter capacities and calculated earthquake damage risk factors based on Model A and C.
Shortest road distances between each SA and TSA (in km) were obtained by utilizing Arcview 9.3 GIS software and Istanbul geographical database.

The mathematical model was written in "zpl" format with ZIMPL programming language, and solved with SCIP (Solving Constraint Integer Programs) Solver version 3.1, on an AMD 8 core 3.00 Gigahertz computer with 8 gigabyte RAM. SCIP is a noncommercial solver for mixed integer programming and mixed integer nonlinear programming and it is also a framework for constraint integer programming and branchcut-and-price (SCIP 2018). Branch-cut-and-price method is a combination of branch-and-price and branch-and-cut 


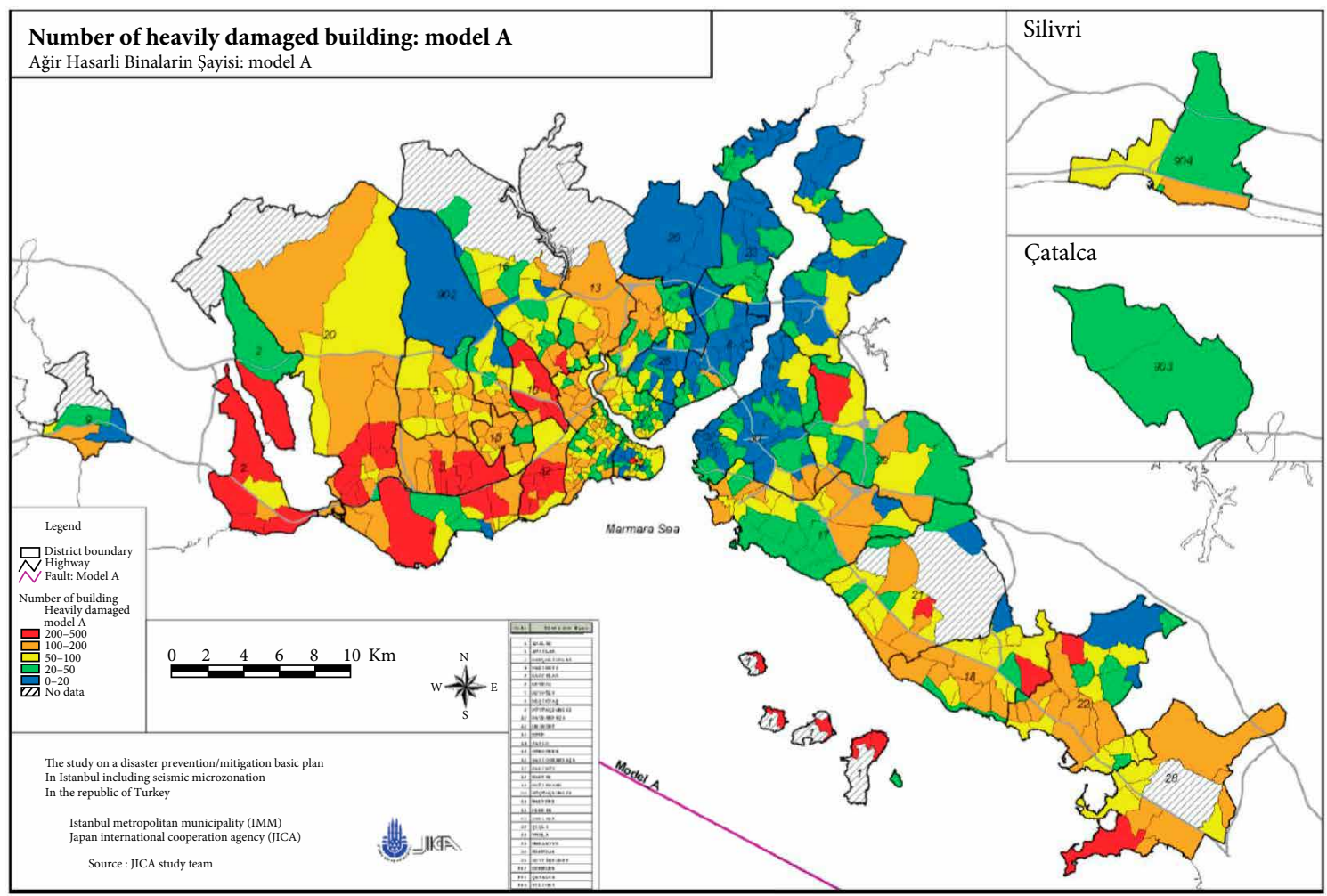

Figure 1: Number of heavily damaged buildings in model A [1].

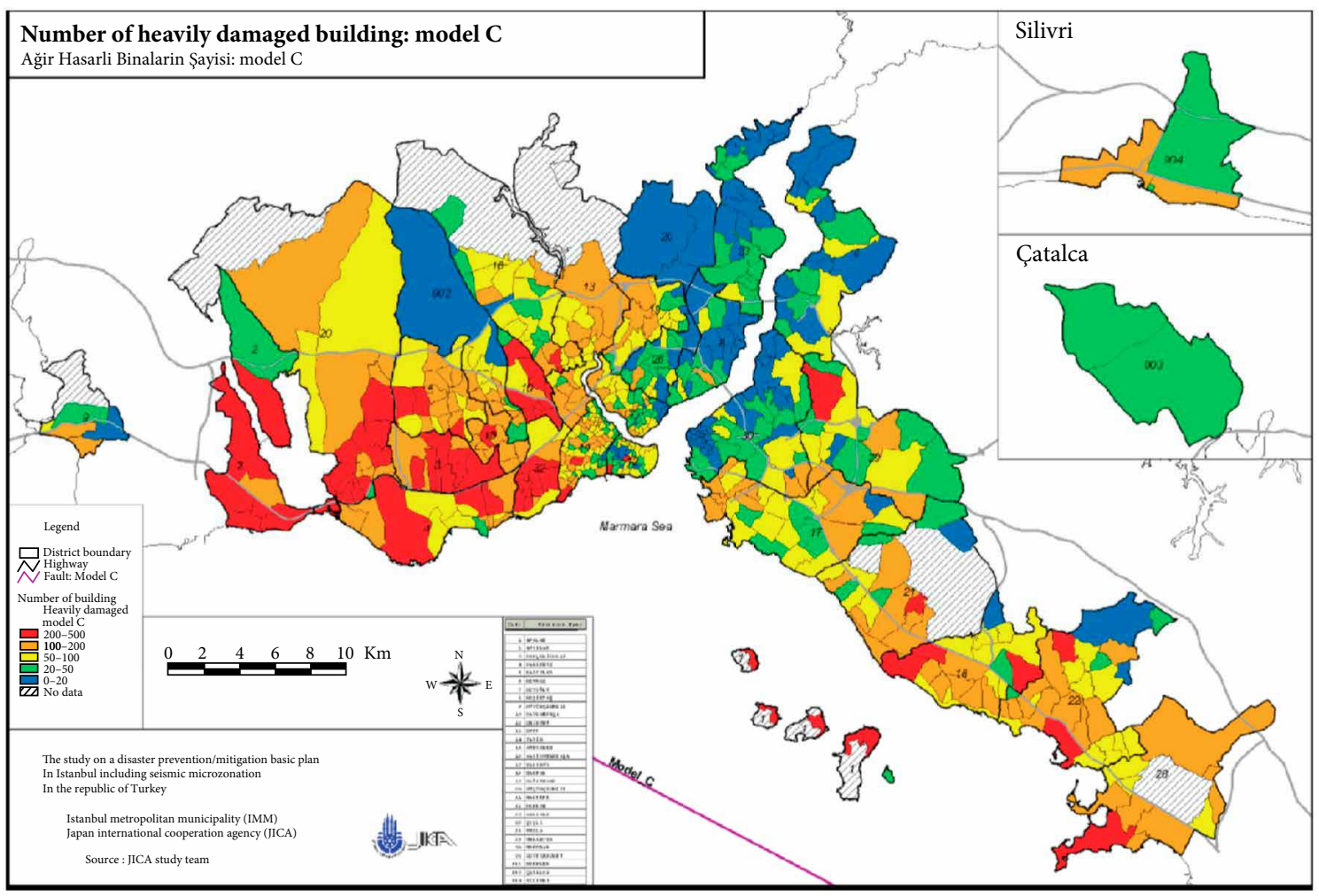

FIGURE 2: Number of heavily damaged buildings in model C [1].

methods. In branch-and-cut, the linear program (LP) relaxation of the sub-problems of branch-and bound is strengthened by cutting planes. In branch-and-price, at each node, the LP relaxation is solved with a column generation approach and whenever one of the implicitly given variables improve the current LP solution, it is added explicitly to the problem 


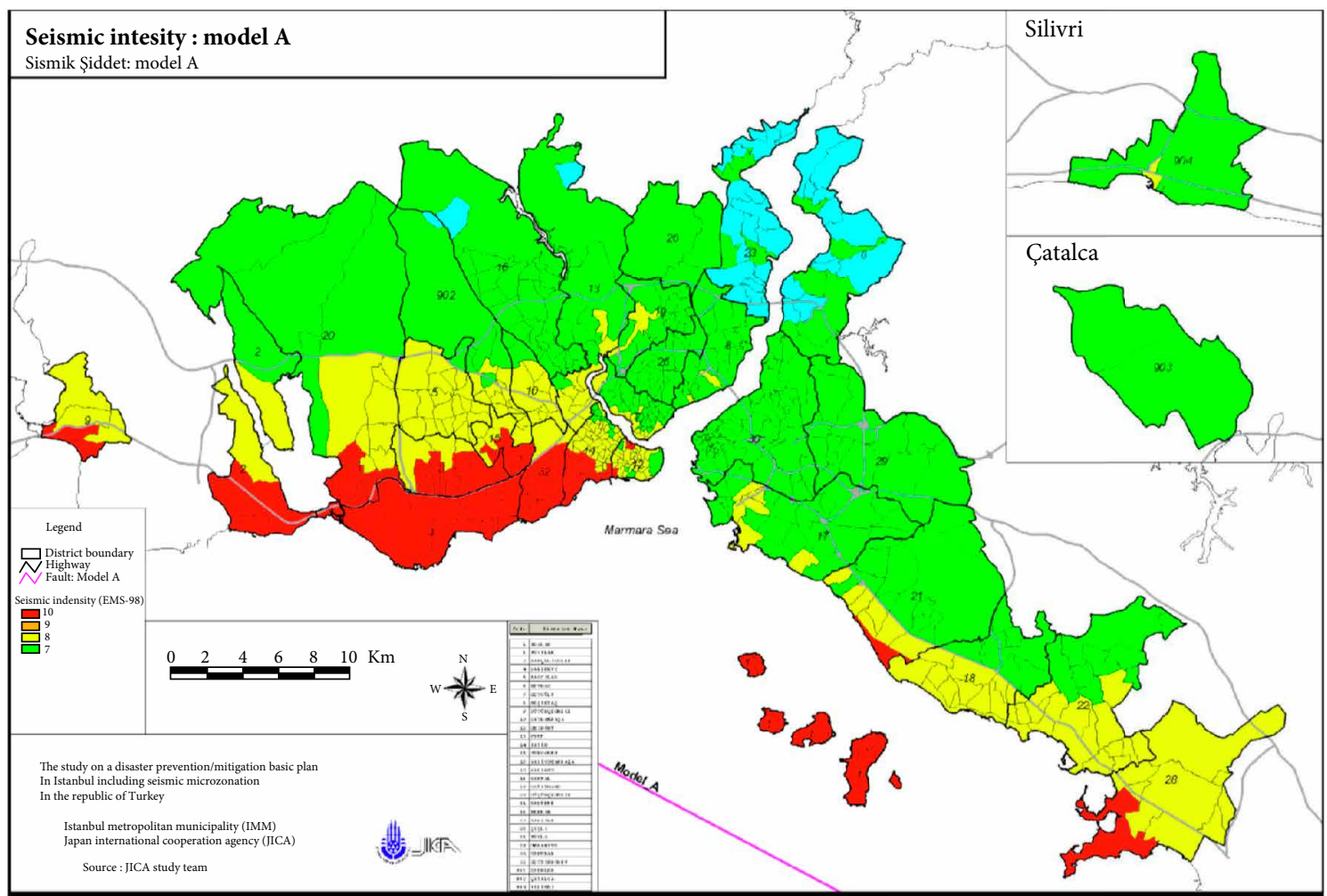

Figure 3: Seismic intensity in model A [1].

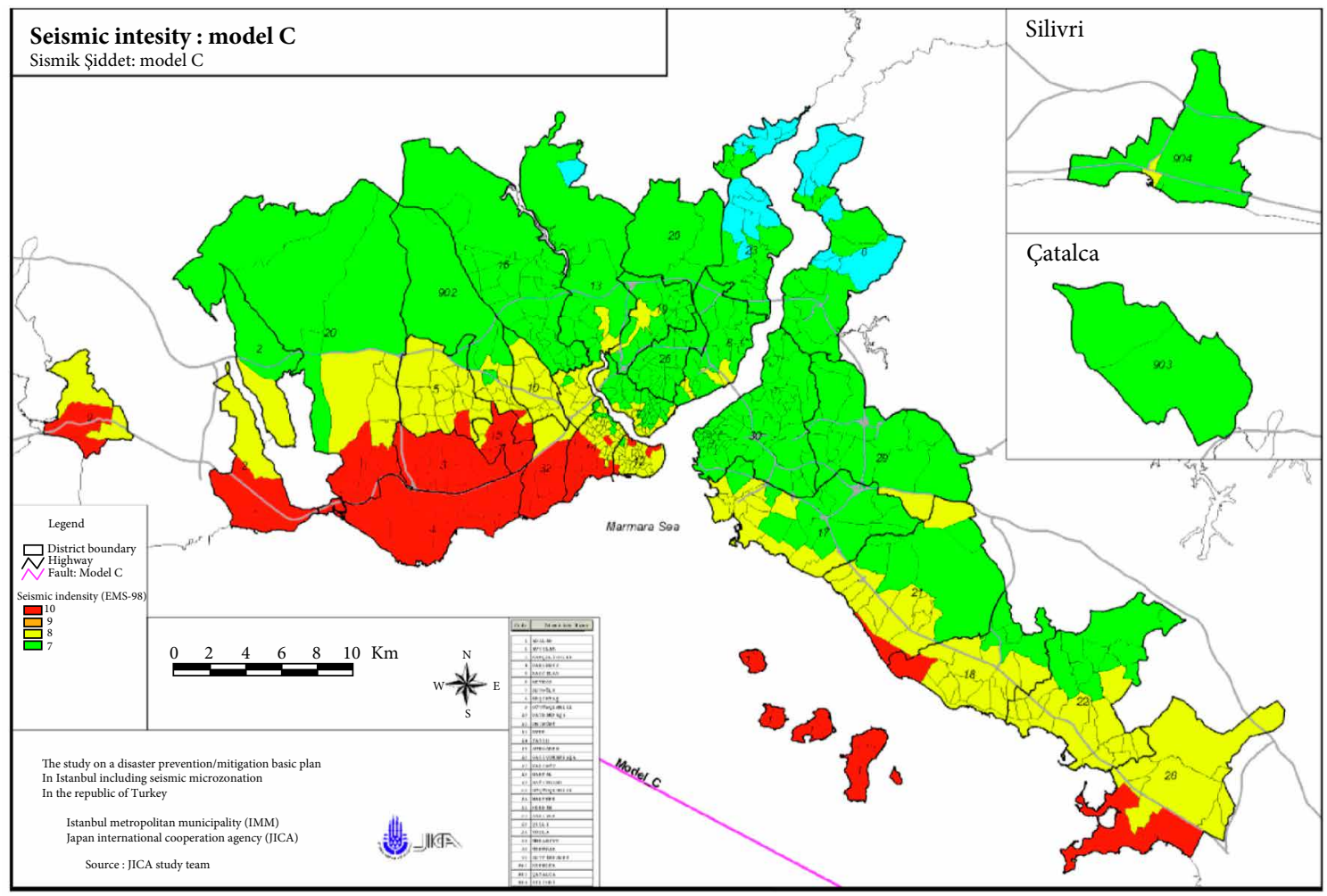

Figure 4: Seismic intensity in model C [1].

$[40,41]$. For each event scenario, each objective function was individually minimized to obtain utopia and nadir points as seen in Table 5.
To determine representative efficient solutions of the problem from the Pareto frontier, a group of 16 dispersed weight vectors were generated in Table 6 , where $w_{i}>0$ are the weights 


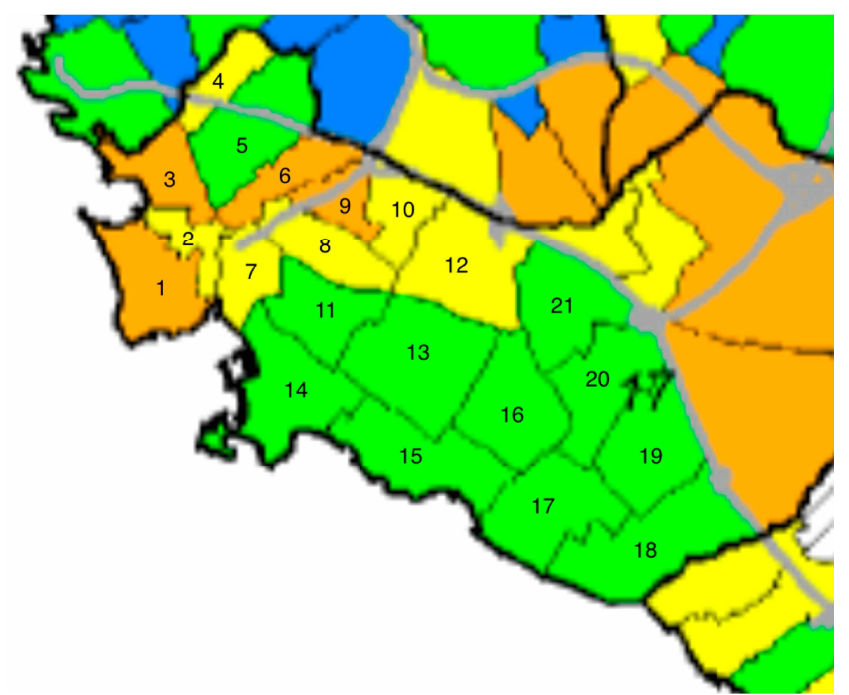

FIGURE 5: Map of number of damaged buildings of Kadiköy for model A [1].

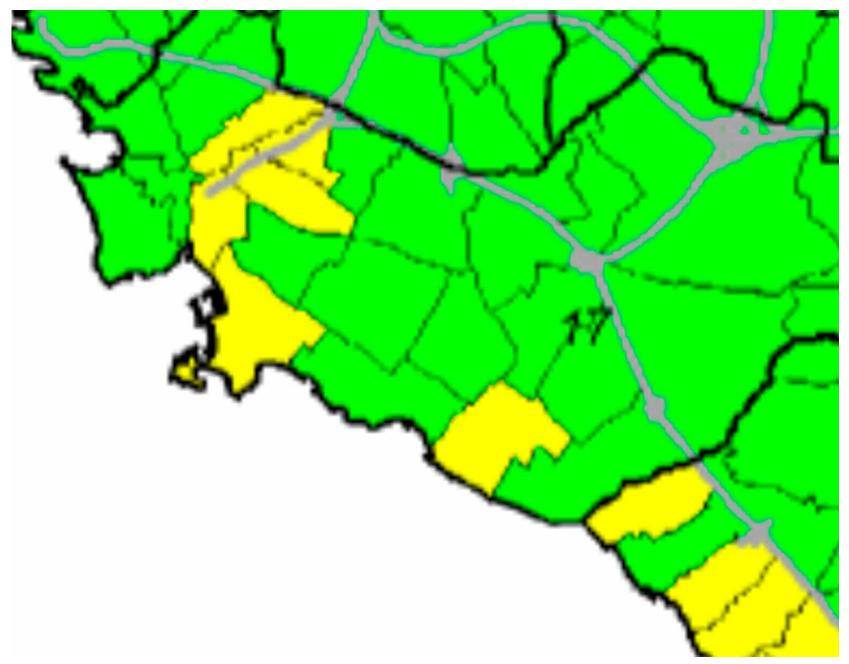

Figure 6: Seismic intensity map of Kadiköy for model A [1].

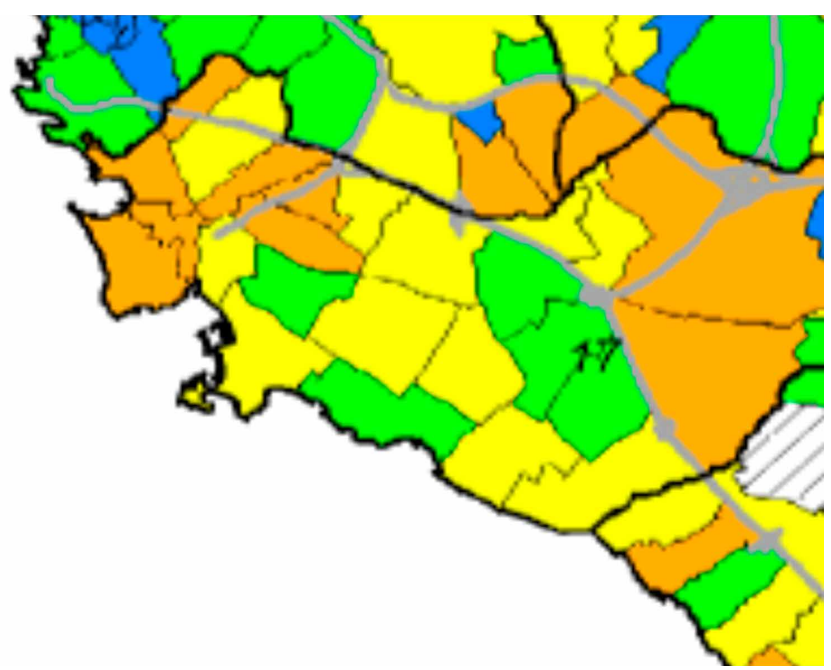

FIGURE 7: Map of number of damaged building of Kadiköy for model C [1].

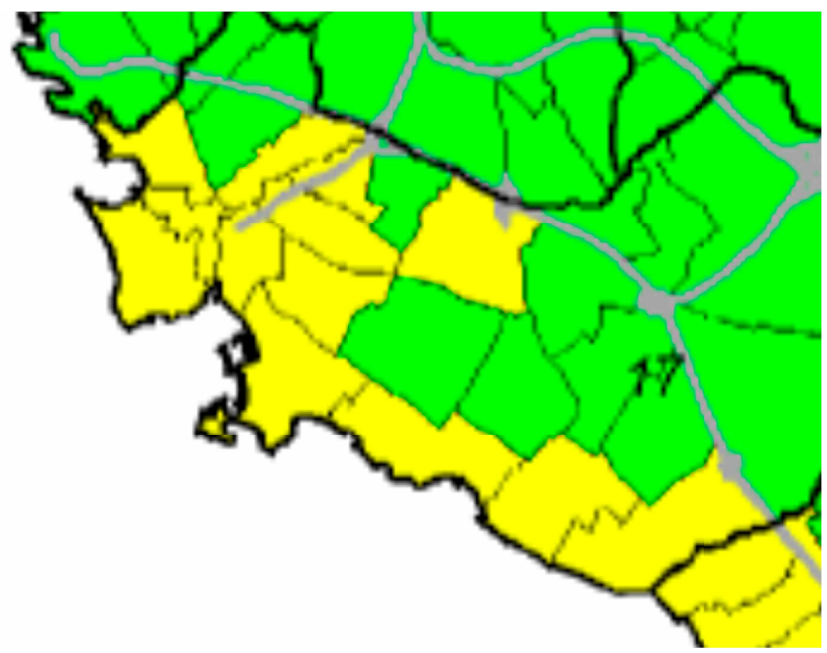

FIGURE 8: Seismic intensity map of Kadiköy for model C [1].

TABLE 5: Utopia and nadir points for each event scenario.

\begin{tabular}{lccccccc}
\hline Scenario 1 & $\min f_{1}(x)$ & $\min f_{2}(x)$ & $\min f_{3}(x)$ & Scenario 2 & $\min f_{1}(x)$ & $\min f_{2}(x)$ & $\min f_{3}(x)$ \\
\hline$f_{1}(x)$ & 0 & 15.25 & 1450.63 & $f_{1}(x)$ & 0 & 15.25 & 1450.63 \\
$f_{2}(x)$ & 225.087 & 3.362 & 225.087 & $f_{2}(x)$ & 227.634 & 3.398 & 227.634 \\
$f_{3}(x)$ & 40179424 & 40179424 & 0 & $f_{3}(x)$ & 41719488 & 41719488 & 0 \\
\hline$f_{i}^{*}(x)=$ & 0 & 3.362 & 0 & $f_{i}^{*}(x)=$ & 0 & 3.398 & 0 \\
$f_{i}^{n}(x)=$ & 1450.63 & 225.087 & 40179424 & $f_{i}^{n}(x)=$ & 1450.63 & 227.634 & 41719488 \\
\hline Scenario 3 & $\min f_{1}(x)$ & $\min f_{2}(x)$ & $\min f_{3}(x)$ & Scenario 4 & $\min f_{1}(x)$ & $\min f_{2}(x)$ & $\min f_{3}(x)$ \\
\hline$f_{1}(x)$ & 0 & 15.25 & 1450.63 & $f_{1}(x)$ & 0 & 15.25 & 1450.63 \\
$f_{2}(x)$ & 230.181 & 3.432 & 230.181 & $f_{2}(x)$ & 232.728 & 3.466 & 232.728 \\
$f_{3}(x)$ & 43259552 & 43259552 & 0 & $f_{3}(x)$ & 44799616 & 44799616 \\
\hline$f_{i}^{*}(x)=$ & 0 & 3.432 & 0 & $f_{i}^{*}(x)=$ & 0 & 3.466 & 0 \\
$f_{i}^{n}(x)=$ & 1450.63 & 230.181 & 43259552 & $f_{i}^{n}(x)=$ & 1450.63 & 232.728
\end{tabular}


TABLE 6: 16 dispersed weight vectors.

\begin{tabular}{|c|c|c|c|c|c|c|c|c|c|c|c|c|c|c|c|c|}
\hline Solution & 1 & 2 & 3 & 4 & 5 & 6 & 7 & 8 & 9 & 10 & 11 & 12 & 13 & 14 & 15 & 16 \\
\hline$w_{1}$ & $1 / 3$ & 0.4 & 0.4 & 0.2 & 0.5 & 0.25 & 0.25 & 0.6 & 0.1 & 0.3 & 0.7 & 0.2 & 0.1 & 0.8 & 0.1 & 0.1 \\
\hline$w_{2}$ & $1 / 3$ & 0.4 & 0.2 & 0.4 & 0.25 & 0.5 & 0.25 & 0.3 & 0.6 & 0.1 & 0.2 & 0.1 & 0.7 & 0.1 & 0.8 & 0.1 \\
\hline$w_{3}$ & $1 / 3$ & 0.2 & 0.4 & 0.4 & 0.25 & 0.25 & 0.5 & 0.1 & 0.3 & 0.6 & 0.1 & 0.7 & 0.2 & 0.1 & 0.1 & 0.8 \\
\hline
\end{tabular}

TABLE 7: 16 representative efficient solutions from the Pareto frontier for each event scenario.

\begin{tabular}{|c|c|c|c|c|c|c|c|c|c|c|}
\hline \multirow[b]{2}{*}{ Sol. no } & \multicolumn{5}{|c|}{ Scenario 1} & \multicolumn{5}{|c|}{ Scenario 2} \\
\hline & $z$ in $(14)$ & $f_{1}(x)$ & $f_{2}(x)$ & $f_{3}(x)$ & $\mathrm{CPU}$ & $z$ in (14) & $f_{1}(x)$ & $f_{2}(x)$ & $f_{3}(x)$ & $\mathrm{CPU}$ \\
\hline 1 & 0.028 & 22.724 & 15.421 & 589526 & 32 & 0.029 & 16.528 & 20.318 & 146560 & 4 \\
\hline 2 & 0.031 & 22.724 & 15.421 & 589526 & 284 & 0.033 & 22.748 & 15.522 & 1164400 & 58 \\
\hline 3 & 0.020 & 13.97 & 20.55 & 73280 & 24 & 0.021 & 14.948 & 20.79 & 146560 & 67036 \\
\hline 4 & 0.030 & 22.724 & 15.421 & 589526 & 6 & 0.034 & 16.528 & 20.318 & 146560 & 4 \\
\hline 5 & 0.025 & 17.114 & 17.225 & 490780 & 205 & 0.025 & 14.948 & 20.79 & 146560 & 8 \\
\hline 6 & 0.035 & 22.724 & 15.421 & 589526 & 79 & 0.038 & 22.748 & 15.522 & 1164400 & 7 \\
\hline 7 & 0.023 & 15.554 & 20.149 & 73.280 & 4 & 0.023 & 15.554 & 20.149 & 146560 & 8010 \\
\hline 8 & 0.027 & 18.604 & 16.158 & 697556 & 214 & 0.028 & 16.618 & 17.46 & 1084400 & 237 \\
\hline 9 & 0.039 & 22.72 & 15.421 & 582200 & 5 & 0.042 & 22.748 & 15.522 & 1084400 & 3 \\
\hline 10 & 0.011 & 14.25 & 22.225 & 0 & 4620 & 0.012 & 15.5 & 22.46 & 0 & 5521 \\
\hline 11 & 0.022 & 16.66 & 17.225 & 589526 & 84 & 0.023 & 14.24 & 20.79 & 246760 & 42 \\
\hline 12 & 0.010 & 14.25 & 22.225 & 0 & 5642 & 0.011 & 15.5 & 22.46 & 0 & 23325 \\
\hline 13 & 0.043 & 22.724 & 15.421 & 582200 & 17 & 0.045 & 22.748 & 15.522 & 1084400 & 12 \\
\hline 14 & 0.015 & 11.747 & 20.886 & 296380 & 4 & 0.016 & 11.198 & 23.858 & 165240 & 8 \\
\hline 15 & 0.041 & 19.275 & 9.761 & 2129496 & 2 & 0.043 & 18.89 & 9.862 & 4258992 & 2 \\
\hline 16 & 0.009 & 15.871 & 21.819 & 0 & 33447 & 0.009 & 17.134 & 21.819 & 0 & 1218 \\
\hline \multicolumn{6}{|c|}{ Scenario 3} & \multicolumn{5}{|c|}{ Scenario 4} \\
\hline Sol. no & $z$ in (14) & $f_{1}(x)$ & $f_{2}(x)$ & $f_{3}(x)$ & $\mathrm{CPU}$ & $z$ in (14) & $f_{1}(x)$ & $f_{2}(x)$ & $f_{3}(x)$ & CPU \\
\hline 1 & 0.031 & 17.502 & 20.487 & 219840 & 34 & 0.031 & 18.476 & 20.656 & 293120 & 546 \\
\hline 2 & 0.036 & 22.772 & 15.623 & 1746600 & 31 & 0.036 & 18.476 & 20.656 & 293120 & 5 \\
\hline 3 & 0.022 & 17.571 & 22.157 & 20040 & 29774 & 0.021 & 18.568 & 22.326 & 0 & 26293 \\
\hline 4 & 0.035 & 17.502 & 20.487 & 219840 & 169 & 0.035 & 18.476 & 20.656 & 293120 & 117 \\
\hline 5 & 0.026 & 17.502 & 20.487 & 219840 & 534 & 0.027 & 18.476 & 20.656 & 293120 & 677 \\
\hline 6 & 0.041 & 22.772 & 15.623 & 1746600 & 12 & 0.042 & 18.476 & 20.656 & 293120 & 3 \\
\hline 7 & 0.024 & 18.33 & 22.157 & 0 & 14146 & 0.024 & 19.58 & 22.326 & 0 & 1493 \\
\hline 8 & 0.029 & 18.152 & 17.157 & 1626600 & 53 & 0.030 & 18.602 & 18.19 & 1540944 & 90 \\
\hline 9 & 0.046 & 22.772 & 15.623 & 1746600 & 6 & 0.048 & 18.88 & 20.656 & 293120 & 4 \\
\hline 10 & 0.012 & 16.75 & 22.695 & 0 & 5382 & 0.012 & 18 & 22.93 & 0 & 25839 \\
\hline 11 & 0.024 & 14.86 & 21.025 & 370140 & 10 & 0.024 & 15.48 & 21.26 & 493520 & 7 \\
\hline 12 & 0.011 & 18.33 & 22.157 & 0 & 21512 & 0.011 & 19.688 & 22.326 & 0 & 31976 \\
\hline 13 & 0.047 & 22.772 & 15.623 & 1746600 & 3 & 0.050 & 22.796 & 15.724 & 2328800 & 3 \\
\hline 14 & 0.016 & 11.526 & 24.688 & 199800 & 42 & 0.017 & 12.168 & 24.924 & 266400 & 100 \\
\hline 15 & 0.044 & 18.505 & 9.963 & 6398508 & 2 & 0.046 & 18.12 & 10.064 & 8517984 & 2 \\
\hline 16 & 0.010 & 18.33 & 22.157 & 0 & 16030 & 0.010 & 19.58 & 22.326 & 0 & 5340 \\
\hline
\end{tabular}

$\left(\sum_{i} w_{i}=1\right)$. Same set of dispersed weight vectors were also used in Samanlioglu's research [42] to find representative efficient solutions. Readers can find methods for generating dispersed weight vectors in Steuer's research [43].

These weight vectors were then used in normalized (scaled) weighted sum formulation of this problem (14) to obtain sample efficient solutions of the Pareto front. For each event scenario, problem (14) was solved 16 times, each with a different weight vector to obtain 16 representative efficient (Pareto optimal) solutions of the problem from the Pareto frontier. In Table 7, these solutions are presented along with CPU times in seconds.

In Tables 8 and 9, shelter distribution plan of a sample efficient solution (solution number 10 of event scenario 3 in (Table 7) is presented for model A (earthquake scenario 1) and $\mathrm{C}$ (earthquake scenario 2). In these tables, expected 
TABLE 8: Expected distribution plan of $10^{\text {th }}$ solution of scenario 3 if model A occurs $\left(X_{n j 1}\right)$.

\begin{tabular}{|c|c|c|c|c|c|c|c|c|c|c|c|c|}
\hline \multirow[b]{2}{*}{ Storage areas } & \multicolumn{12}{|c|}{ Temporary shelter areas } \\
\hline & 100 & 101 & 102 & 103 & 104 & 105 & 106 & 107 & 108 & 109 & 110 & 111 \\
\hline 27 & - & - & - & - & - & - & - & - & - & - & 250 & - \\
\hline 34 & - & - & - & - & - & - & - & - & - & - & - & 480 \\
\hline 57 & - & - & - & - & - & - & - & - & 750 & - & - & - \\
\hline 59 & - & - & - & - & - & - & - & - & 610 & - & - & - \\
\hline 64 & - & - & 400 & 352 & 128 & - & - & - & - & - & - & - \\
\hline 85 & - & - & - & - & - & 960 & - & - & - & - & - & - \\
\hline 86 & - & - & - & - & - & - & - & - & 560 & 1440 & - & - \\
\hline 87 & 192 & 272 & - & - & - & - & 128 & - & - & - & - & - \\
\hline 88 & - & - & - & - & - & - & - & 304 & - & - & 870 & - \\
\hline
\end{tabular}

TABLE 9: Expected distribution plan of $10^{\text {th }}$ solution of scenario 3 if model C occurs $\left(X_{n j 2}\right)$.

\begin{tabular}{lcccccccccccc}
\hline \multicolumn{1}{c}{ Semporary shelter areas } \\
\hline 27 & 100 & 101 & 102 & 103 & 104 & 105 & 106 & 107 & 108 & 109 & 110 & 111 \\
34 & - & - & - & - & - & - & - & - & - & - & 150 & 100 \\
57 & - & - & - & - & - & - & - & - & - & - & - & 500 \\
59 & - & - & - & - & - & - & - & - & 750 & - & - & - \\
64 & - & - & - & - & - & - & - & - & 750 & - & - & - \\
85 & - & - & - & 440 & 160 & 650 & - & - & - & - & - & - \\
86 & 240 & - & 500 & - & - & - & 160 & - & - & - & - & - \\
87 & - & - & - & - & - & - & - & - & 200 & 1800 & - & - \\
88 & - & 340 & - & - & - & 550 & - & 330 & - & - & - & - \\
\hline
\end{tabular}
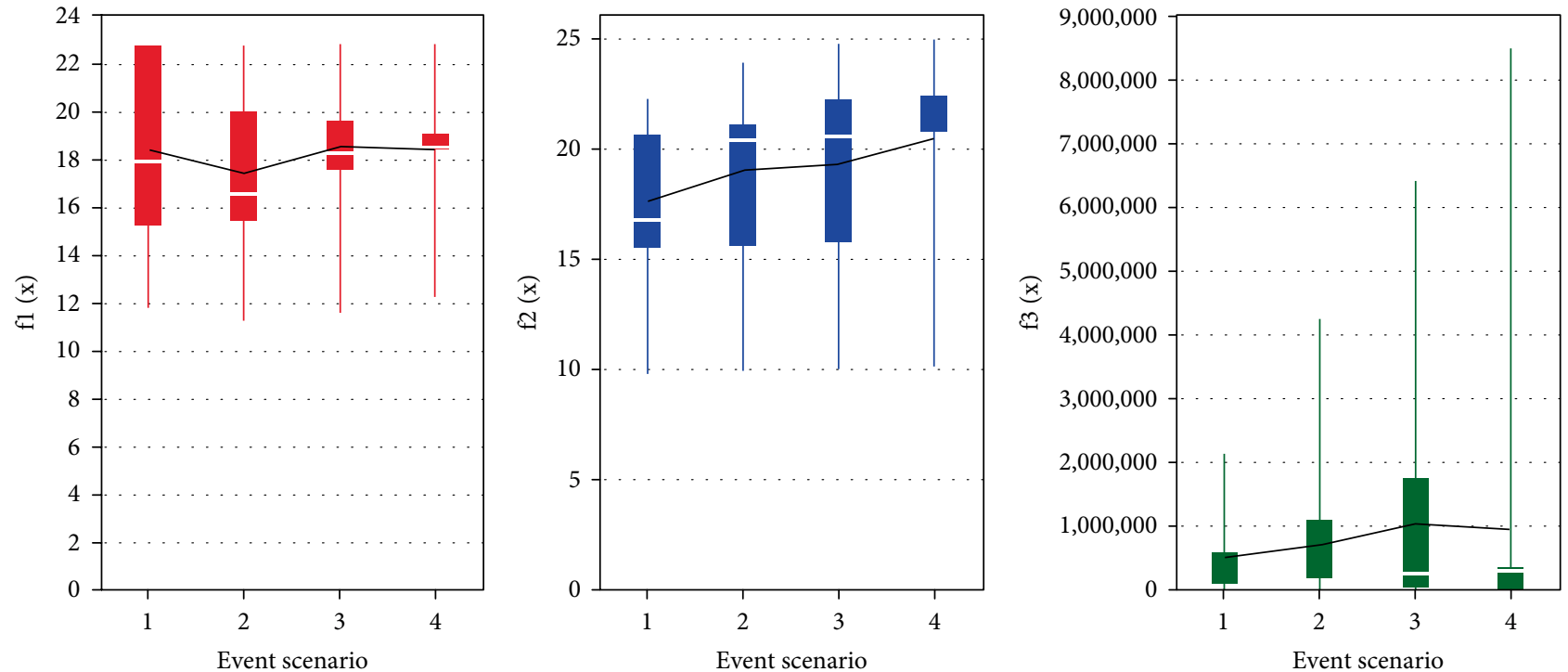

FIGURE 9: Box plots and means of objective functions according to event scenarios.

quantities of shelters that will be shipped from selected SA and TSA are given, and based on this sample efficient solution, all the shelter demands of TSA are satisfied for both earthquake scenarios, which can also be confirmed by the 0 value of $f_{3}(x)$ in Table 7. Also, Tables 8 and 9 show that changes in demand between earthquake scenarios (model A and C) affect the distribution process. The number of links between supply and demand points increase from 15 (model A) to 19 (model C).
Due to the nature of stochastic multi-criteria decision problem, the decision process has strategic importance. Proposed results show that while some of the solutions remain persistent along changing event scenarios, some of them may change dramatically. For instance, solution 7 in Table 7 provides solutions with fully satisfied demand for event scenarios 3 and 4 but there is unsatisfied demand for event scenarios 1 and 2. Figure 9 shows box plots and means of each objective 
function against event scenario probabilities. Objective function 2 (total expected earthquake damage risk factor) is sensitive to scenario probabilities since there is an increase in mean and median values with respect to event scenarios. On the other hand, for objective function 1 , it can be concluded that the mean of the total expected distribution distance is not sensitive to scenario probabilities. Additionally, all of the objective functions are sensitive to event scenario probabilities in terms of variance within the results of objective functions.

\section{Conclusions}

In this study, a stochastic multi-objective mixed integer mathematical model for the location and distribution decisions in an earthquake relief network was developed. The model includes some aspects that can be seen in the literature; however, none of the existing models in the relief network literature simultaneously include decisions related to: pre-earthquake shelter storage at SA and post-earthquake shelter distribution from SA to TSA while taking into consideration storage capacity restrictions, earthquake scenario dependent demand, earthquake damage risk factor of SA, and coverage distance restrictions.

In this paper, three potentially conflicting significant criteria that needs to be minimized simultaneously were presented. These are; minimization of total expected distribution distance between SA and TSA, minimization of total expected earthquake damage risk factor of SA, and minimization of total expected unsatisfied demand penalty cost of TSA. To obtain efficient solutions from the Pareto frontier, as the multi-criteria decision making method, normalized (scaled) weighted summethod was implemented for its simplicity. For each event scenario, representative Pareto optimal solutions for the problem were obtained, by generating dispersed weight vectors and solving the problem each time with different weight vectors. In reality, these weights are assigned to each objective function depending on decision-makers' preferences, specifically importance they give to each objective.

The model was implemented in a pilot area; Kadikoy municipality of Istanbul, Turkey and based on these results, suggestions were made to the municipality. While some assumptions were made due to a lack of some information, in the implementation, many real-life aspects of the earthquake relief network were considered and realistically implemented in the model. In the implementation, 12 TSA and 88 SA were taken into consideration and related data was obtained from Kadikoy municipality of Istanbul, IMM, and JICA report [1]. In the application, four event scenarios with two earthquake scenarios (model A and C presented in JICA report [1]), having different likelihoods, were created. Mathematical model was written with ZIMPL programming language and solved by SCIP Solver. The computational effort is reasonable since this problem is a multi-criteria strategic decision making problem which will be solved infrequently.

For future research, to solve larger problems in a shorter time, an efficient heuristic may be developed. In the mathematical model, minimization of total storage and distribution costs were not taken into consideration since for relief networks, generally priority is given to improving the temporary life quality of survivors rather than budget issues, however if there are also strict budget limitations, storage and distribution costs should be included in the model besides penalty cost for unsatisfied demand. Also, as part of future research direction, in the model, minimization of total distribution time, and the effects of possible traffic and road closures may be taken into consideration.

\section{Data Availability}

The data needed is in the manuscript and no other data is available.

\section{Conflicts of Interest}

The authors declare that they have no conflicts of interest.

\section{References}

[1] JICA, "The study on disaster prevention/mitigation basic plan," vol. 16, no. 12, pp. 899-900, 2002, https://www.preventionweb. net/go/43027.

[2] K. Sinasi, L. Gary, and P. J. Curran, "Displaying earthquake damage in an urban area using a vegetation-ous-soil model and remotely sensed data," in Proceedings of the International Society for Photogrammetry and Remote Sensing Conference, pp. 634-638, 2004.

[3] M. Sahin and E. Tari, "The august 17 kocaeli and the november 12 duzce earthquakes in Turkey," Earth, Planets and Space, vol. 52, no. 10, pp. 753-757, 2000.

[4] R. Logendran and M. P. Terrell, "Uncapacitated plant locationallocation problems with price sensitive stochastic demands," Computers \& Operations Research, vol. 15, no. 2, pp. 189-198, 1988.

[5] F. V. Louveaux and D. Peeters, "A dual-based procedure for stochastic facility location," Operations Research, vol. 40, no. 3, pp. 564-573, 1992.

[6] G. Laporte, F. V. Louveaux, and L. van Hamme, "Exact solution to a location problem with stochastic demands," Transportation Science, vol. 28, no. 2, pp. 95-103, 1994.

[7] S. M. Mousavi and S. T. A. Niaki, "Capacitated location allocation problem with stochastic location and fuzzy demand: a hybrid algorithm," Applied Mathematical Modelling, vol. 37, no. 7, pp. 5109-5119, 2013.

[8] Yolanda M. Carson and Rajan Batta, "Locating an ambulance on the amherst campus of the state university of New York at buffalo," Interfaces, vol. 20, no. 5, pp. 43-49, 1990.

[9] A. M. Mestre, M. D. Oliveira, and A. P. Barbosa-Póvoa, "Location-allocation approaches for hospital network planning under uncertainty," European Journal of Operational Research, vol. 240, no. 3, pp. 791-806, 2014.

[10] D. P. Michalopoulos, D. P. Morton, and J. W. Barnes, "Prioritizing network interdiction of nuclear smuggling," in Stochastic Programming, vol. 4, pp. 313-346, 2012.

[11] H. L. Khoo and L. E. Teoh, "An optimal aircraft fleet management decision model under uncertainty," Journal of Advanced Transportation, vol. 48, no. 7, pp. 798-820, 2014.

[12] N. Altay and W. G. Green, "OR/MS research in disaster operations management," European Journal of Operational Research, vol. 175, no. 1, pp. 475-93, 2006. 
[13] Aakil M. Caunhye, Xiaofeng Nie, and Shaligram Pokharel, "Optimization models in emergency logistics: a literature review," Socio-Economic Planning Sciences, vol. 46, no. 1, pp. 4-13, 2012.

[14] A. M. Anaya-Arenas, J. Renaud, and A. Ruiz, "Relief distribution networks: a systematic review," Annals of Operations Research, vol. 223, no. 1, pp. 53-79, 2014.

[15] E. Grass and K. Fischer, "Two-stage stochastic programming in disaster management: a literature survey," Surveys in Operations Research and Management Science, vol. 21, no. 2, pp. 85-100, 2016.

[16] A. Trivedi and A. Singh, "Facility location in humanitarian relief: a review," International Journal of Emergency Management, vol. 14, no. 3, pp. 213-232, 2018.

[17] G. Barbarosoğlu and Y. Arda, "A Two-stage stochastic programming framework for tansportation panning in dsaster response," Journal of the Operational Research Society, vol. 55, no. 1, pp. 43-53, 2004.

[18] E. S. Chia, "Engineering disaster relief," in IEEE International Symposium on Technology and Society, November 2006.

[19] W. Yi and L. Özdamar, "A dynamic logistics coordination model for evacuation and support in disaster response activities," European Journal of Operational Research, vol. 179, no. 3, pp. 1177-1193, 2007.

[20] B. Balcik and B. M. Beamon, "Facility location in humanitarian relief," International Journal of Logistics Research and Applications, vol. 11, no. 2, pp. 101-21, 2008.

[21] C. G. Rawls and M. A. Turnquist, "Pre-positioning of emergency supplies for disaster response," Transportation Research Part B: Methodological, vol. 44, no. 4, pp. 521-534, 2010.

[22] Serhan Duran, Marco A. Gutierrez, and Pinar Keskinocak, "Pre-positioning of emergency items for care international," Interfaces, vol. 41, no. 3, pp. 223-37, 2011.

[23] L. B. Davis, F. Samanlioglu, X. Qu, and S. Root, "Inventory planning and coordination in disaster relief efforts," International Journal of Production Economics, vol. 141, no. 2, pp. 561-573, 2013.

[24] J. A. Paul and L. MacDonald, "Location and capacity allocations decisions to mitigate the impacts of unexpected disasters," European Journal of Operational Research, vol. 251, no. 1, pp. 252-263, 2016.

[25] F. Cavdur, M. Kose-Kucuk, and A. Sebatli, "Allocation of temporary disaster response facilities under demand uncertainty: an earthquake case study," International Journal of Disaster Risk Reduction, vol. 19, pp. 159-66, 2016.

[26] E. Celik, N. Aydin, and A. T. Gumus, "A stochastic location and allocation model for critical items to response largescale emergencies: a case of Turkey," International Journal of Optimization \& Control: Theories \& Applications, vol. 7, no. 1, pp. 1-15, 2017.

[27] R. Maharjan and S. Hanaoka, "Warehouse location determination for humanitarian relief distribution in Nepal," Transportation Research Procedia, vol. 25, pp. 1151-1163, 2017.

[28] A. Mohamadi and S. Yaghoubi, "A Bi-objective stochastic model for emergency medical services network design with backup services for disasters under disruptions: an earthquake case study," International Journal of Disaster Risk Reduction, vol. 23, pp. 204-217, 2017.

[29] J. B. Sheu, "Dynamic relief-demand management for emergency logistics operations under large-scale disasters," Transportation
Research Part E: Logistics and Transportation Review, vol. 46, no. 1, pp. 1-17, 2010.

[30] H. O. Mete and Z. B. Zabinsky, "Stochastic optimization of medical supply location and distribution in disaster management," International Journal of Production Economics, vol. 126, no. 1, pp. 76-84, 2010.

[31] J. Zhang, M. Dong, and F. Frank Chen, "A bottleneck steiner tree based multi-objective location model and intelligent optimization of emergency logistics systems," Robotics and Computer-Integrated Manufacturing, vol. 29, no. 3, pp. 48-55, 2013.

[32] Ali Bozorgi-Amiri, M. S. Jabalameli, and S. M. J. Mirzapour Ale-Hashem, "A Multi-ojective rbust sochastic pogramming mdel for dsaster relief logistics under uncertainty," OR Spectrum, vol. 35, no. 4, pp. 905-33, 2013.

[33] M. Najafi, K. Eshghi, and W. Dullaert, "A multi-objective robust optimization model for logistics planning in the earthquake response phase," Transportation Research Part E: Logistics and Transportation Review, vol. 49, no. 1, pp. 217-249, 2013.

[34] F. Liberatore, M. T. Ortuño, G. Tirado, B. Vitoriano, and M. P. Scaparra, "A hierarchical compromise model for the joint optimization of recovery operations and distribution of emergency goods in humanitarian logistics," Computers and Operations Research, vol. 42, pp. 3-13, 2014.

[35] J.-D. Hong, K.-Y. Jeong, Y. Xie, and Management Engineering, "A multi-objective approach to planning in emergency logistics network design," International Journal of Industrial Engineering, vol. 22, no. 4, pp. 412-25, 2015.

[36] S. Tofighi, S. A. Torabi, and S. A. Mansouri, "Humanitarian logistics network design under mixed uncertainty," European Journal of Operational Research, vol. 250, no. 1, pp. 239-250, 2016.

[37] A. Moreno, D. Alem, D. Ferreira, and A. Clark, "An effective two-stage stochastic multi-trip location-transportation model with social concerns in relief supply chains," European Journal of Operational Research, vol. 269, no. 3, pp. 1050-1071, 2018.

[38] R. T. Marler and J. S. Arora, "The weighted sum method for multi-objective optimization: new insights," Structural and Multidisciplinary Optimization, vol. 41, no. 6, pp. 853-862, 2010.

[39] W. Chen, G. Zhai, C. Ren, Y. Shi, and J. Zhang, "Urban resources selection and allocation for emergency shelters: in a multihazard environment," International Journal of Environmental Research and Public Health, vol. 15, no. 6, 2018.

[40] G. Gamrath, ““'Generic branch-cut-and-price”. Master's Thesis," Institut Für Mathematik, Technischen Universitat Berlin, http:// scholar.google.com/scholar?hl=en\&btnG=Search\&q=intitle:G eneric+Branch-Cut-and-Price\#2, 2010.

[41] J. Desrosiers and M. E. Lübbecke, “'Branch-price-and-cut algorithms',' Wiley Encyclopedia of Operations Research and Management Science (EORMS), 2011.

[42] F. Samanlioglu, "A multi-objective mathematical model for the industrial hazardous waste location-routing problem," European Journal of Operational Research, vol. 226, no. 2, pp. 332-340, 2013.

[43] R. E. Steuer, Multiple Criteria Optimization: Theory, Computation, and Application. Wiley Series in Probability and Mathematical Statistics, Wiley, 1986, https://books.google.com. tr/books?id=2YxeAQAACAAJ. 


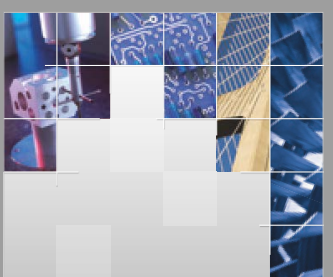

\section{Enfincering}
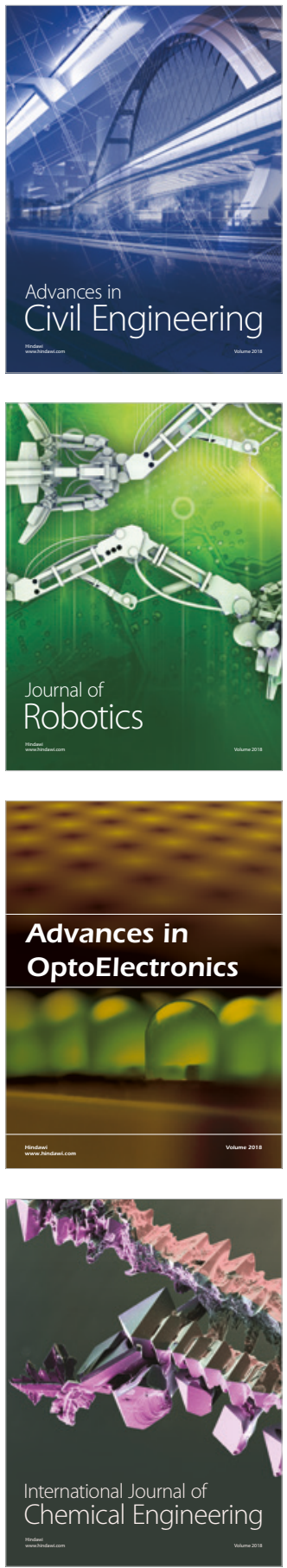

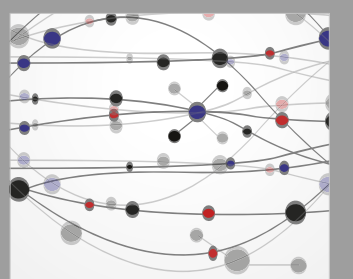

\section{Rotating \\ Machinery}

The Scientific World Journal

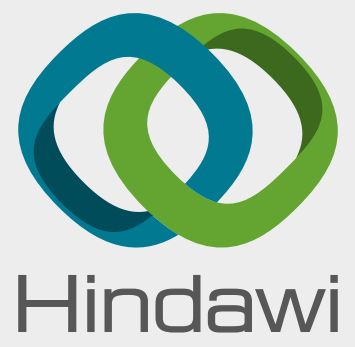

Submit your manuscripts at

www.hindawi.com
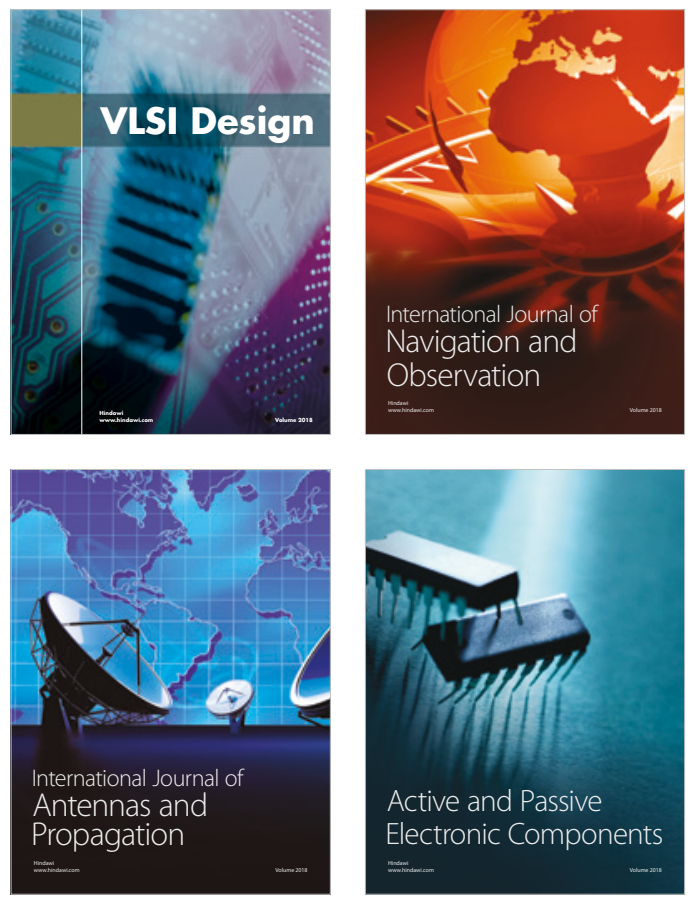
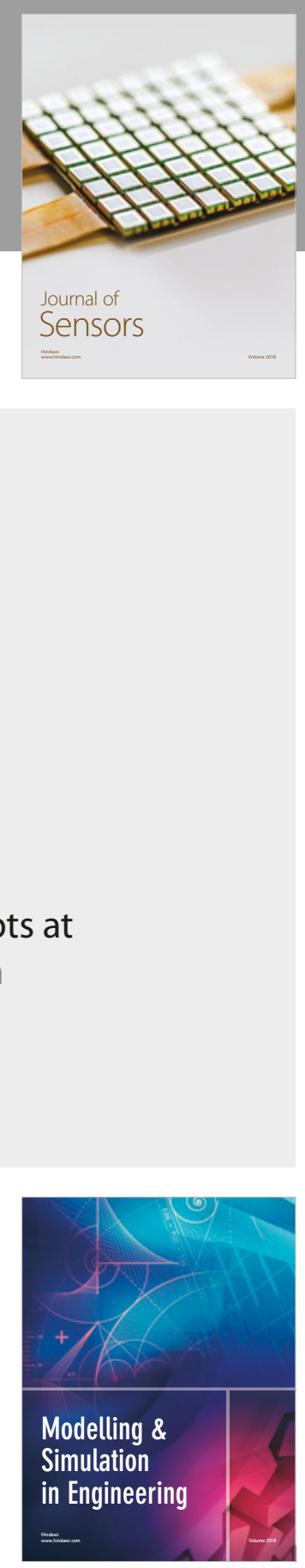

\section{Advances \\ Multimedia}
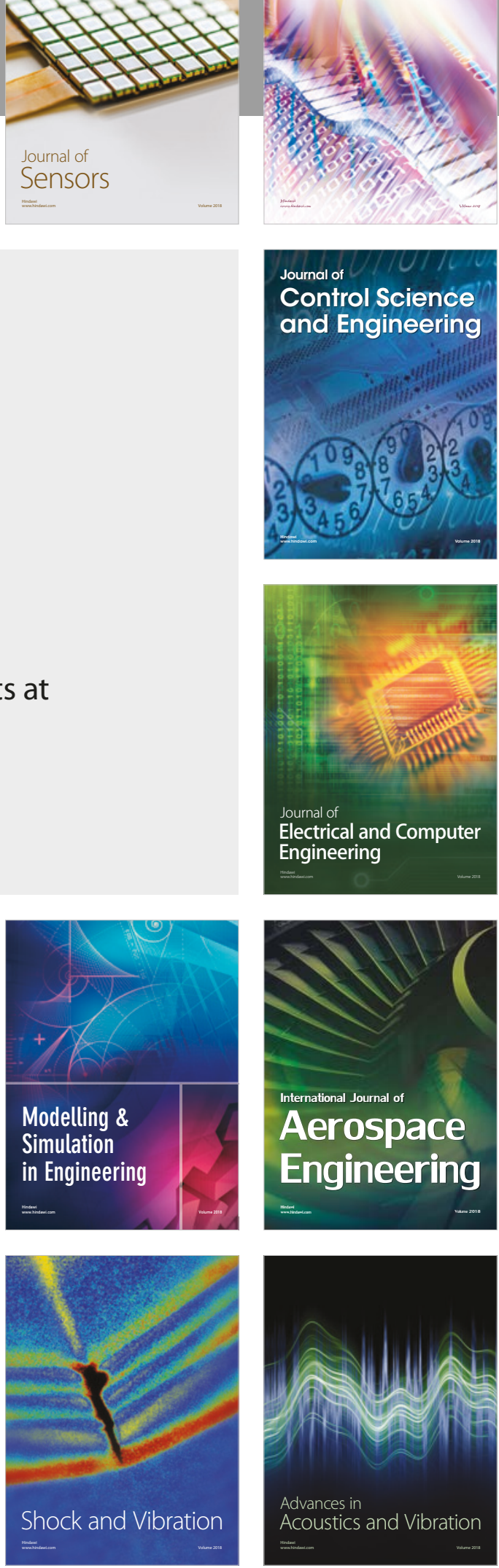